\title{
Molecular Biology of Atherosclerotic Ischemic Strokes
}

\author{
Antonino Tuttolomondo *, Maria Grazia Puleo, Maria Chiara Velardo, Francesca Corpora, \\ Mario Daidone (ID and Antonio Pinto \\ Department of Health Promotion, Maternal and Infant Care, Internal Medicine and Medical Specialties, \\ “G. D'Alessandro", University of Palermo, Piazza delle Cliniche n.2, 90127 Palermo, Italy; \\ dott.ssamgpuleo@gmail.com (M.G.P.); mariachiara.velardo@libero.it (M.C.V.); \\ francesca.corpora@gmail.com (F.C.); mariodaidone@gmail.com (M.D.); antonio.pinto@unipa.it (A.P.) \\ * Correspondence: bruno.tuttolomondo@unipa.it
}

Received: 21 November 2020; Accepted: 3 December 2020; Published: 9 December 2020

\begin{abstract}
Among the causes of global death and disability, ischemic stroke (also known as cerebral ischemia) plays a pivotal role, by determining the highest number of worldwide mortality, behind cardiomyopathies, affecting 30 million people. The etiopathogenetic burden of a cerebrovascular accident could be brain ischemia $(\sim 80 \%)$ or intracranial hemorrhage $(\sim 20 \%)$. The most common site when ischemia occurs is the one is perfused by middle cerebral arteries. Worse prognosis and disablement consequent to brain damage occur in elderly patients or affected by neurological impairment, hypertension, dyslipidemia, and diabetes. Since, in the coming years, estimates predict an exponential increase of people who have diabetes, the disease mentioned above constitutes together with stroke a severe social and economic burden. In diabetic patients after an ischemic stroke, an exorbitant activation of inflammatory molecular pathways and ongoing inflammation is responsible for more severe brain injury and impairment, promoting the advancement of ischemic stroke and diabetes. Considering that the ominous prognosis of ischemic brain damage could by partially clarified by way of already known risk factors the auspice would be modifying poor outcome in the post-stroke phase detecting novel biomolecules associated with poor prognosis and targeting them for revolutionary therapeutic strategies.
\end{abstract}

Keywords: ischemic stroke; neuroinflammation; atherosclerosis; microglia; NLRP3 inflammasome; DKK-3; Dectin-1; MKEY; microRNAs; CD200-CD200R; AF; BBB

\section{Introduction}

Stroke is termed as a sudden onset of focal or global symptoms and clinical signs, due to an abrupt occlusion or rupture of a blood cerebral vessel which determines consequential brain suffering through cerebral hypoperfusion or resultant compression by hemorrhage.

Clinical manifestations persist more than $24 \mathrm{~h}$, and neuroimaging techniques like CT or MRI could additionally uphold diagnosis.

The high incidence worldwide of stroke, associated with elevated mortality and morbidity, makes this chronic problem a plague of the whole human society.

Every year 15 million people are afflicted by a cerebrovascular accident, and epidemiological data show that one-third of them go to death, and another one-third is affected by a severe physical and psychological disability.

Several studies suggested a correlation between the incidence of stroke and ethnic factors; Hispanic and Black people have a significant risk to be suffering from the invalidating pathology above-mentioned compared to Caucasians in the United States [1]. 
Therefore, identifying new etiopathogenetic factors of an ischemic cerebrovascular event is necessary with the intention to find new therapeutic regimens capable of affecting prognosis and quality of life of patients.

There are two primary physiopathological dichotomous substrates: Ischemia and haemorrhage.

In the first circumstance, a discrepancy between intracellular oxygen requirement and brain inflow occurs due to an occlusion of a brain blood vessel by a clot (thrombus or embolus). In contrast, in the second case, the hematic extravasation consequent to vascular rupture provokes compression of adjacent brain parenchyma. Brain ischemia constitutes the most common physiopathological entity of a cerebrovascular lesion.

Five distinct subcategories of stroke are described by TOAST classification [2]. They could be largetartery atherosclerosis ( $45 \%$ of the total of events), cardioembolism (15-30\%), systemic hypoperfusion, penetrating artery disease, carotid dissection, hypercoagulability of genetic syndromes or with an undetermined etiology.

Several processes like atherosclerosis, endothelial dysfunction and neuroinflammation subtend the pathophysiology of ischemic stroke.

A substantial contribution to the etiopathogenesis of ischemic damage is made by the immune system which not only mediates inflammatory cascade but also determines an immune suppression, due to the effects of the vegetative nervous system, overactivated by cerebral lesion, on the lymphoid system.

Therefore, increased susceptibility to elapsing infections takes place, and it provokes a further increase of chance of mortality and morbidity after a cerebrovascular accident [3,4].

Iadecola and Anrather have drawn up a list of mediators implicated in all phases of neuroinflammation in ischemic stroke, from the beginning to the resolution. The onset of neuroinflammation after brain injury is mediated by mediators like "TNF- $\alpha$, IL1 $\alpha$, IL1 $\beta$, CXCL7, CCL5, CXCL4, CX3CL1, adhesion molecules, proteases, prostanoids, and leukotrienes"; "IL-1, IL-10, TNF- $\alpha$, IL- 6, IL-20, IL-17", and "NADPH oxidase, CXCL8, iNOS, and COX-2" are involved in the phase of boosting of this process and other molecules including "TGF- $\beta$, IL-17, IL-10, and IL-23" mediate its termination [5]. Other molecules such as NLRP3 inflammasome, DKK-3, Dectin-1, MKEY, and microRNAs are implicated in neuroinflammation so ongoing, and future researches about the intricate mechanism related could lead to pioneering therapeutic interventions that could considerably modify the natural course of this invalidating condition.

The pathobiology of stroke is utterly characterized, besides the activation of innate immunity which exacerbates brain harm through the release of inflammatory cues, by the co-participation of the adaptative immune system, elicited by massive exposure to several antigens, due to the blood-brain barrier (BBB).

In this review, we take into consideration the noxious and the curative properties of some mediators of neuroinflammation, focusing on the role of the innate and adaptative immune system and the contribution made by atrial fibrillation. Besides, we investigate the relationship between neuroinflammation and BBB dysfunction and miRNAs that plays a pivotal role in the pathogenesis of stroke, representing potentially promising therapeutic targets. We have chosen to deepen some biomolecules and related pathways which are described in very recent researches in literature and whose modulation probably could circumscribe the damaged area after a stroke, preventing the ruinous effects of inflammation on brain lesion.

\section{The Role of the Innate Immune System in Neuroinflammation}

As many evidences have demonstrated, neuroinflammation could be defined as an inflammatory response to insults derived from several pathogenic noxae related to different pathologies such as ischemic stroke [6,7]. In the latter case, neuronal death is responsible for the initiation of an inflammatory cascade piloted by chemokines, cytokines, and ROS. 
Furthermore, various cell types which are involved in this process and are members of the innate immune system shall be liable of necrosis and apoptosis of cerebral cells, resulting in a further increase of brain lesion size and a more severe cognitive impairment and disability [8-10].

Plenty of reviews in worldwide literature treat about general aspects the pathogenetic contribution of several inflammatory cytokines and the involvement of various cell types such as neutrophils, microglia, and astrocytes in neuroinflammation, after an ischemic stroke.

Consequently, we preferred to explore other recently in-depth biomolecular pathways, which modulation could be established future opportunities for innovative strategies of treatment (Table 1).

Table 1. Key biological molecular patterns of innate immune system implied in neuroinflammation.

\begin{tabular}{|c|c|c|}
\hline Evidence & Findings & References \\
\hline $\begin{array}{c}\text { NLRP3 inflammasome is one of the main } \\
\text { contributors to the process of } \\
\text { neuroinflammation and consequent } \\
\text { brain damage. }\end{array}$ & $\begin{array}{l}\text { NLRP3 inflammasome is responsible for } \\
\text { activation of IL-1 } \beta \text {, and the release of IL-18, } \\
\text { which phosphorylate IRS-1, worsening } \\
\text { insulin-resistance and causing } \\
\text { neuronal death. }\end{array}$ & {$[11,12]$} \\
\hline $\begin{array}{l}\text { High levels or low levels of DKK-3 } \\
\text { worsen outcome after an ischemic stroke. }\end{array}$ & $\begin{array}{l}\text { DKK-3 concentrations have an impact on } \\
\text { endothelial dysfunction and atherosclerosis. } \\
\text { The crosstalk between Dectin-1 and DAMPs }\end{array}$ & {$[13,14]$} \\
\hline $\begin{array}{l}\text { The inflammatory pathway mediated by } \\
\text { Dectin-1/Syk has a pivotal role in } \\
\text { neuroinflammation after a stroke. }\end{array}$ & $\begin{array}{l}\text { determines phosphorylation of ITAM and, } \\
\text { subsequently, of Syk, a kinase which mediates } \\
\text { a cascade of neuroinflammation and the } \\
\text { release of several cytokines. }\end{array}$ & [15] \\
\hline $\begin{array}{l}\text { The heterodimer CXCL4-CCL5 plays a } \\
\text { crucial part in the cerebral injury. }\end{array}$ & $\begin{array}{l}\text { Avoiding the formation of CXCL4-CCL5 } \\
\text { heterodimer, MKEY, a cyclic peptide } \\
\text { synthesized on the base of CCL5 in mice, } \\
\text { restricts the ischemic cerebral lesion and } \\
\text { ameliorate neurologic deficits in mice. } \\
\text { Studies sugoested the existence of an }\end{array}$ & {$[16,17]$} \\
\hline $\begin{array}{l}\text { The microglial IRF5-IRF4 regulatory axis } \\
\text { impacts stroke outcomes. }\end{array}$ & $\begin{array}{l}\text { IRF5-IRF4regulatory axis in which IRF5 } \\
\text { signaling mediates microglial } \\
\text { pro-inflammatory responses and IRF4 } \\
\text { signaling enhances microglial } \\
\text { anti-inflammatory activation. }\end{array}$ & {$[18,19]$} \\
\hline $\begin{array}{l}\text { CD200 could play an important role in } \\
\text { therapeutic strategies for the treatment of } \\
\text { ischemic stroke by way of the inhibition of } \\
\text { detrimental leukocyte activation and } \\
\text { improvement of stroke-induced } \\
\text { lymphopenia. }\end{array}$ & $\begin{array}{l}\text { The loss of interplay between CD200-CD200R } \\
\text { will induce microglial proliferation and } \\
\text { activation that may exacerbate the process of } \\
\text { neuroinflammation and aggravate the } \\
\text { prognosis after stroke. }\end{array}$ & [20] \\
\hline $\begin{array}{l}\text { The glial glutamate transporter (GLT-1), } \\
\text { an astrocytes' transporter, performs } \\
\text { neuroprotective effects in the initial } \\
\text { phases of ischemia. }\end{array}$ & $\begin{array}{c}\text { It determines the formation of a glial scar } \\
\text { which has a neuroprotective role because it } \\
\text { safeguards salubrious tissues from damages } \\
\text { attributable to inflammation. }\end{array}$ & {$[21,22]$} \\
\hline
\end{tabular}

\subsection{NLRP3 Inflammasome}

Several diseases such as autoinflammatory pathologies, diabetes, and stroke share the pathogenetic mechanism of inflammation, mediated by many molecules like cytokines, some of which are characterized by pro-inflammatory features. Between the latter, the interleukin $1 \beta$ plays a pivotal part and, as many studies have illustrated, it can trigger and modulate the drop-down pathways of inflammation, through the interaction with inflammasome $[23,24]$.

In the release of cytokines get involved different cellular sensing elements of the innate immune system, many of them belonged to the family of NOD-like receptor (nucleotide-binding oligomerization domain-like receptor), also called NLR. The latter distinguish themselves for the presence of the domain NACHT. It consists of the acronym of its most significant proteic components like a protein 
that inhibits neuronal apoptosis (NAIP), an activator of the transcription of class $2 \mathrm{MCH}$ (C2TA), heterokaryon incompatibility, and the protein one telomerase-associated (TP1) [25].

A C-terminal leucine-rich repeat (LRR) and pyrin domains (PYD) or N-terminal caspase recruitment (CARD) enwrap the core of NATCH [26,27]. Different researches focused on NAPL3 also termed cryopyrin or NLRP3 (NLR family pyrin domain-containing 3) inflammasome, a member of the NOD-like receptor family codified by the gene NLRP3 [25]. It is indeed one of the main contributors to the process of neuroinflammation and the consequent brain damage in patients who have type 2 diabetes and cerebrovascular accident $[28,29]$. Moreover, the downregulation of NLRP3 could represent a powerful therapeutic approach in both the subtype of subjects aforementioned [30,31].

A sensor made up of three different domains of NLRP3 (PYD domain-containing protein, LRR and NACHT), an adaptor (ASC; also known as PYCARD) and an effector (caspase 1, a cysteine-dependent aspartate-directed protease 1) assembling themselves generate the structure of NLRP3 inflammasome.

In the event of an infection by pathogenic exogenous micro-organisms or after an intracellular injury, many distress signals such as uric acid and even hexokinase cause the activation of detriment-associated pathways. NLRP3 inflammasome has the capacity of recognizing these warnings, activating caspase 1 thanks to a previous interaction between ASC and pro-caspase 1 and having a significant impact on inflammatory mediators like IL-18 and IL-1 $\beta[32,33]$.

It is therefore intuitive that NLRP3 inflammasome may play a pivotal role in neuroinflammation after a cerebrovascular accident, provoking the apoptosis of glial cells and neurons. In these cells, oxidative stress and endoplasmic reticulum stress is exacerbated by the release of inflammatory molecules and the activation of IL-1R signaling-IRS-1 pathway and the involvement of NLRP3 and NLRP1 inflammasome. The significant increase in the production of ROS and the continuing of NLRP3 activation aggravates cerebral damage and impairment, boosting edema and atherosclerosis processes [34,35]. This inflammasome is responsible for elevated levels of TNF- $\alpha$ (tumo necrosis-factor- $\alpha$ ), a cytokine which plays a crucial role in insulin insensitivity and endothelial dysfunction [36]. Moreover, cells belonging to the innate immune system, especially microglia and macrophages, release high concentrations of IL-1 $\beta$. The molecule above-mentioned worsens cerebral disablement after an ischemic stroke in diabetic patients and aggravates insulin-resistance when the comorbidity of severe obesity is present [11,12] (Figure 1).

Considering the physiopathologic implications of inflammasomes in neuroinflammation, a process responsible for poor prognosis, the therapeutic use of mediators involved in these pathways could be advantageous.

It has been shown that glyburide, sinomenine, MCC950, and other molecules reduce insulin resistance, delay advancement of ischemic brain injury, decreasing the extent and improve neurologic loss and clinical consequences.

Besides, recent evidence demonstrates that the inhibition of VDUP1 which is the acronym of vitamin D3up-regulated protein 1 (also termed TXNIP, thioredoxin-interacting protein), a signal molecule inducing the activation of NLRP3 inflammasome [37], improves brain damage. It represents a further confirmation that the crosstalk between NLRP3 inflammasome and VDUP1 can be considered a pathogenetic mechanism of ischemic stroke [38].

\subsection{DICKKOPFF-3 (DKK-3)}

Dkk-3, the acronym of Dickkopf-3 (Dkk-3), is a member of the family DKK. It is a protein which controls Wnt $/ \beta$-catenin signaling pathway, decides cellular differentiation during embryogenesis $[39,40]$ and conditions metabolism of vascular cells, decreeing their proliferative and survival fate [41]. Besides, it could also have a significant impact on the advancement of atherosclerotic burden, as recent studies established [13,42].

When Dkk-3 is overexpressed, the inhibiting action on the signaling pathway mentioned above [39,40,43], could power atherosclerosis and injuries related worsening prognosis [13] through the accretion of plaques inside the vascular lumen. 


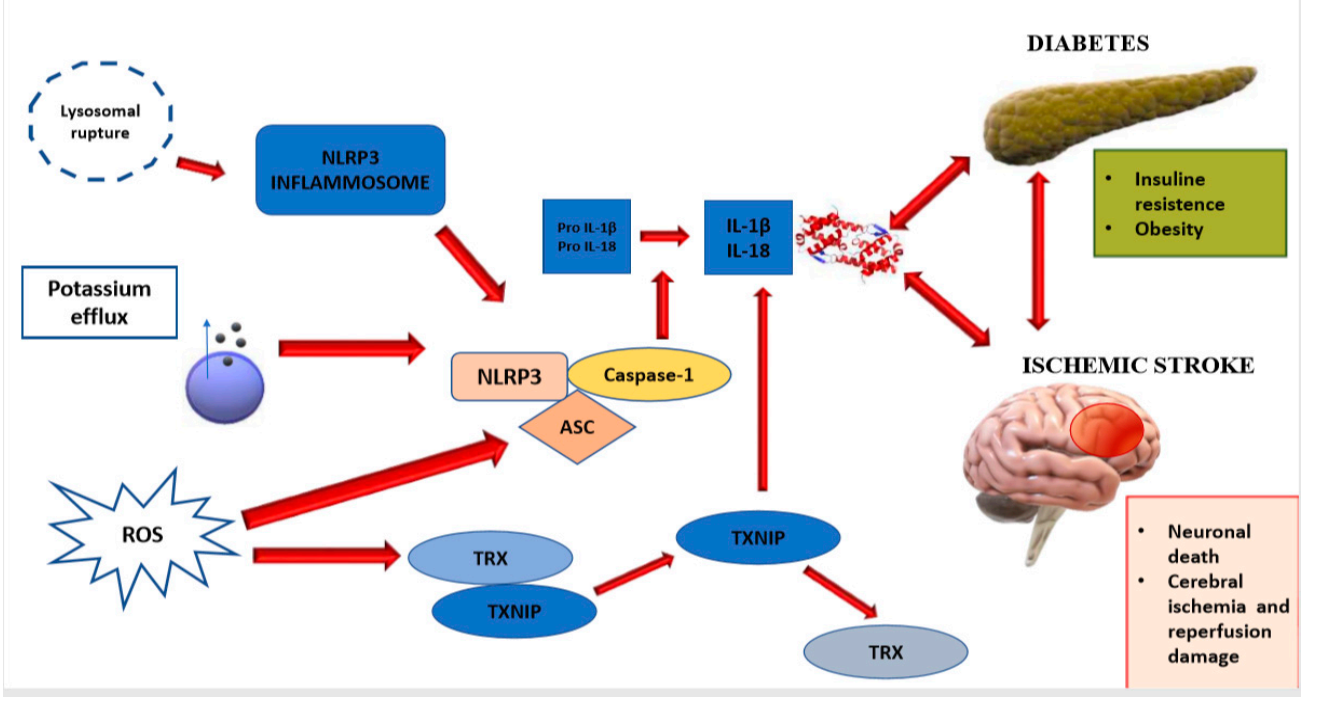

Figure 1. The NLRP3 inflammasome plays a fundamental part in the process of neuroinflammation consequent to a cerebrovascular accident, particularly in diabetic patients in which enhances the progression of metabolic disorder. The figure above illustrates three hypothetic etiopathogenetic factors such as lysosomal rupture, ROS and cellular potassium efflux, which are co-responsible of the activation of caspase 1, triggering the release of mediators of inflammation like cytokines IL-18 and IL- $1 \beta$. In the macrophages of adipose tissue, the activation of NLRP3 inflammasome is determined by the release of DNA and the production of ROS in mitochondria, through the desegregation of TRX-TXNIP complex. After its triggering, NLRP3 inflammasome provokes the cleavage of pro-IL-1 $\beta$ into IL1-1 $\beta$, the active form, and the release of IL-18. These cytokines phosphorylate IRS-1, as known as the insulin receptor substrate-1, worsening insulin- resistance and causing neuronal death.

Dkk-3, indeed, regulates the angiogenetic process repressing the growth of endothelial cells determining low expression levels of VEGF (vascular endothelial growth factor) [40,44]. In contrast, a study of mice with a deficit of Apo-E shown that the underexpression of Dkk-3 could restrict the extension of atherosclerotic lesions and ameliorate the stability of plaques [13].

On the other hand, since it is an essential regulator of cell fate determination [14,45], Dkk3 was also mentioned to have a protective function against atherosclerosis. It is involved in the process of reconstitution of the endothelium in both phases of migration and repair. It also prevents the accretion of a new innermost layer of vessels in the presence of an atherosclerotic lesion, after triggering JNK pathway. In a study in knock-out mice for the gene DKK-3 with a subsequently failed expression of this protein, a significant endothelial dysfunction has been reported, evidenced by an inversely proportional relationship between the middle-intimate layer of the carotid artery and plasmatic levels of DKK-3 [31]. Given these assumptions, the goal could be represented by keeping plasmatic and tissue of the protein mentioned above within a well-defined range in physiologic conditions [14].

The study CATIS, a large-sample multicentric trial [46], demonstrated worse clinical outcomes in patients affected by an ischemic stroke, whether in the presence of high levels either of low levels of DKK-3. These findings were corroborated further by subgroup analyses, and they suggested that the relationship between DKK-3 and morbidity and mortality for cardiovascular events after an ischemic stroke follows a U-shaped trend because both the excessive and the deficient expressions predispose poor clinical consequences.

\subsection{DECTIN-1/SYK}

Several features and mechanisms influence the physiopathology of ischemic stroke. It is a well-established finding that, among all of them, neuroinflammation has greater importance in the 
determining the advancement of brain injury $[5,30]$ through microglia, neuronal, and endothelial cells and other cell types belonging to the innate immune system [5].

The better prognosis observed in patients affected by an acute cerebrovascular event, after the inhibition of inflammatory pathways, represents a further finding that confirms the previous assessment [47,48].

One of these inflammatory pathways, which plays a pivotal role in neuroinflammation, is mediated by Dectin- 1 and Syk, a protein with tyrosine kinase activity mainly expressed in microglia. Many pro-inflammatory signals and DAMPs, which constitutes the acronym of danger-associated molecular patterns, are identified by dendritic cells, especially some of them characterized by the expression of C-type lectin-1 (Dectin-1), thanks to the interaction with Syk [49-51]. In case of an inflammatory process, a higher expression of Dectin-1, a transmembrane receptor of II type, could be observed in several cell types such as Tlymphocytes, dendritic cells, monocytes, neutrophil granulocytes, and cells of the epithelium [52-55].

Under physiological conditions, a low concentration of the molecule above-mentioned can be found in cerebral parenchyma; instead, it is considerably expressed when a brain injury occurs as a defensive response against damage stimuli $[56,57]$. Besides, it has been shown that it has an impact on the activation of inflammasome NLRP3 after the interaction with $\beta$-glucan particles [58-60], the subsequent augmented synthesis of ROS, and it is involved in the increased release of interleukine $\beta[58,61,62]$. The inhibition of Dectin- 1 could ameliorate spinal cord injury because it antagonizes the harmful macrophagic activity, impeding axonal damage and demyelination of nerve fibers and promotes the process of neurogenesis [63,64].

The immunoreceptor hemITAMs, an incomplete ITAMs, is common to different types of C-type lectin receptors, like C-type lectin-like receptor 2 (also known as CLEC2), C-type lectin domain-containing 9A (which acronym is CLEC9A) and Dectin-1 and it plays a crucial part in the interaction with Syk [65]. This protein could be expressed in cells belonged to the hematopoietic system, but it can also be found in other cell types [66,67]. It constitutes one of the most significant leader features of ischemic brain injury mediated by acutely and chronically inflammation [68-72]. Syk is triggered by engaging molecules released by cells went forward necrosis [73-75] (Figure 2).

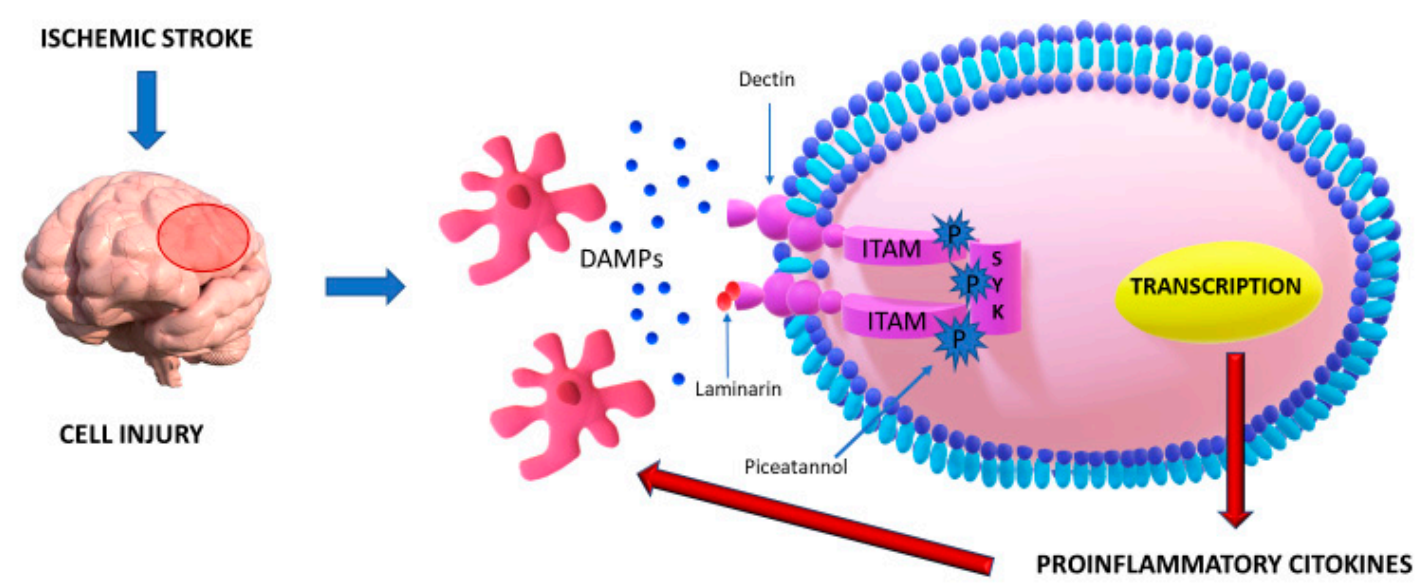

Figure 2. Dectin-1, also known as Dendritic cell-associated C-type lectin-1, a receptor activated by the interaction with DAMPs (damage-associated molecular patterns), is responsible for an innate immune response when brain damage such cerebral ischemia occurs. The crosstalk between Dectin-1 and DAMPs determines phosphorylation of ITAM and, subsequently, of Syk, a kinase which mediates a cascade of neuroinflammation and the release of several cytokines. Some antagonist molecules of Dectin-1 like Syk inhibitor piceatannol and laminarin can underregulate this process, reducing the detrimental effects of neuroinflammation on brain damage after a stroke. 
Once triggered, Syk (p-Syk) empowers the activation of a cascade constituted by different transcription factors such as PKB, p85, NF- $\mathrm{kB}$, and PDK1 which codify proteins as COX-2, iNOS, and TNF- $\alpha$; all molecules with pro-inflammatory proprieties [59,60,76-79].

In literature, various scientific researches have investigated the characteristic manifestations of neuroinflammation. Xin-Chun Ye et al. achieved this purpose examining the variation of concentrations of some inflammatory mediators such as Syk, Dectin-1, TNF- $\alpha$, p-Syk, and inducible nitric oxide synthase (iNOS) in ischemic cerebral tissue of mice using in vitro and in vivo methods [15]. Tissue expression levels in damaged cerebral parenchyma after ischemia were found substantially augmented and they exert deleterious effects, enhancing the number of activated microglia and increasing neuroinflammation. Besides, they assessed that antagonizing the activity of Dectin-1 and Syk through respectively Dectin-1 antagonist laminarin (LAM) and Syk inhibitor piceatannol (PIC) results in a decreased synthesis of pro-inflammatory molecules levels and attenuated the number of activated microglia with a consequential reduction of neurological deficits. This finding could represent a novel therapeutic strategy capable of circumscribing ischemic damage, relieving organic and functional brain injury.

\subsection{CXCL4-CCL5 Heterodimer}

Macrophagic activities in the brain during a stroke are regulated by several inflammatory molecules, such as chemokines [80,81], small polypeptide categorized into four subsets like XC, CC, CX3C, and CXC [80,82]. CXCL4 is one of the most important of chemokines belonged to the category of the CXC subgroup because it has an impact on inflammation after an ischemic stroke [83-86], and CCL5 of the subgroup of CC modulates leukocyte migration. Besides, the relationship between CCL5 and its receptor CCR5, induces inflammatory response, cytophylaxis, and signal transcription [87].

Macrophages stem from brain resident microglia and circulating monocytes. A few hours after stroke onset, resident microglia and bloodstream monocytes are activated instantly and differentiate to macrophages. Microglia and monocyte-derived macrophages (indicated respectively with the acronyms MiMФs and MoMФs) do not differ from a morphological point of view should therefore be discernible identifying cell-surface markers through analyses which employ flow cytometric technique. Microglia-derived macrophages are CD45intCD11b+, instead monocyte-derived macrophages are $\mathrm{CD} 45 \mathrm{hiCD} 1 \mathrm{~b}+$. Furthermore, macrophages could be distinguished by additional markers such as CX3CR1, CCR2, and Ly6C.

During neuroinflammation, the capability of CCL5 of promoting monocyte adhesion and migration, consequentially to stimulation of CCR5, is empowered by establishment of the heterodimer.

The formation of CXCL4-CCL5 heterodimer could be void by a cyclic peptide synthesized on the base of CCL5 in mice called MKEY [16].

Evidence has shown that this inhibitor, preventing the assembly of the heterodimer mentioned above, is significantly capable of restrict the ischemic cerebral lesion and ameliorate neurologic deficits in mice, confirming once again the involvement of CXCL4-CCL5 in cerebral injury.

Besides, CCL5 and CCR5 could play a pivotal role in neuroinflammation in consideration of augmented expression of CCR5 on the surface of both subtypes of macrophages and increased levels of CCL5 in damaged parenchyma. In this way, the molecule, as mentioned above is responsible for the recruitment of white blood cells near the ischemic lesion [88], exacerbating inflammation, tissue detriment, and cerebral impairment [17]. Moreover, Yifang Fan et al. have also demonstrated that MKEY has the feature to suppress the activity of the MPO positive neutrophils, CD68-positive macrophages, and infiltrating monocytes-derived macrophages considerably, but not macrophages derived from microglia [89]. This assessment suggests that MKEY has a beneficial impact on the phenomenon of neuroinflammation right for the inhibition of monocytes-derived macrophages. 


\subsection{Microglial IRF5-IRF4 Regulatory Axis}

Cerebral ischemic damage gets worse even for the role of the innate immune system because microglia could contribute to a secondary neuronal injury $[90,91]$ and resident cerebral immune cells participate at ischemic pathophysiology, representing the main characters of the process of neuroinflammation [92].

Cuartero et al. supposed that neutrophils could assume a protective role in neuroinflammation after a stroke, shifting toward an N2 phenotype. They obtain this result by resorting to PPAR- $\gamma$, also known as peroxisome proliferator-activated receptor- $\gamma$, responsible for a mechanism of polarization. N2 neutrophils express M2 markers like CD206 that is a mannose receptor and Ym1 (also termed Chi313 or chitinase 3-like 3). They are related to increased neutrophil clearance, essential for resolving inflammation and neuroprotection. Besides, in literature, several studies postulate a significant relationship between neutrophils and endothelial cells [93]; indeed, cerebral endothelial cells after an ischemic event release CSF3 (Colony Stimulating Factor 3). This molecule determines the activation of neutrophil granulocytes, which, considering the dangerous activity of a scavenger receptor called CD36, causes toxic effects in damaged parenchyma.

Immune cells could acquire two different phenotypes "M1 and M2," respectively, because they have two activation states after pathogenic stimulation that could lead or not to neuroinflammation, according to the inflammatory environment [92]. The first phenotype, M1, activated by realizing soluble FAS ligand, plays a part in ischemic lesion inducing the production of cytokines which enhanced inflammation and augmented infarct extent; the second phenotype M2, induced by IL-4, is characterized by neuroprotective properties, facilitating phagocytosis and enhancing neuroplasticity after stroke [94]. The reduction of microglia worsens postischemic inflammation, and brain damage in a study led on young mice $[95,96]$, indicating that microglia are useful to reduce ischemic injury and are not merely neurotoxic.

Macrophage activation is mediated by interferon regulatory factors (IRF) in peripheral immune cells and other inflammatory diseases [18]. Recent studies have demonstrated that IRF5 and IRF4 expression in microglia exhibited a "see-saw" pattern and corresponded with pro-and anti-inflammatory profiles, respectively, after stroke [19]. These studies suggested the existence of an IRF5-IRF4 regulatory axis in which IRF5 signaling mediates microglial pro-inflammatory responses and IRF4 signaling enhances microglial anti-inflammatory activation, and as a result, the IRF5-IRF4 regulatory axis impacts stroke outcomes.

In contrast with other acute pathological changes (calcium overloading oxidative stress and others), the immune response to ischemic injury culminates later and lasts for months poststroke $[97,98]$, offering us a more extended time window to do therapeutic acts to improve stroke outcomes potentially.

The microglial IRF5IRF4 regulatory axis can be potentially targeted to treat ischemic stroke and other neuroinflammatory diseases. Cell-specific therapy opens the door to new therapeutic possibilities represented by siRNA techniques and lentiviral vectors $[99,100]$. It constitutes a therapeutic line due to their capability to more precisely target cell-specific signaling pathways, eluding more global changes in immune regulation. Consequently, pharmacological reagents could be developed to reduce IRF5 or increase IRF4 expression in microglia after stroke, so that the pro-inflammatory response can be prevented and the anti-inflammatory response trigger earlier to clear the ischemic detriment and boost the tissue repair.

\subsection{The Role of CD200-CD200R Interaction in Neuroinflammation after Stroke}

In the scientific world, it is a well-established finding that neuroinflammation represents one of the prominent contributors to the pathogenetic mechanism of ischemic stroke, dramatically influencing the prognosis [101].

Therefore, different constituent elements belonged to the innate immune system are responsible for a protecting response against brain injury [102], through the release of mediators that promote brain regeneration. Moreover, several studies have also shown that after brain damage, other molecules 
may be responsible for brain impairment, hampering the process of neurogenesis and breaking the blood-brain barrier [9].

Hoek et al. demonstrated that after an ischemic stroke, neurons can enact a self-defense process across an interaction between CD200, an integral membrane glycoprotein member of immunoglobulin superfamily and CD200R, expressed on the microglial surface [103].

The inhibitory crosstalk realized between the ligand CD200 and its receptor called CD200R inhibitory immune ligand-receptor constitutes one of the most advantageous immunoregulatory systems that may avoid the release of pro-inflammatory cytokines in cerebral damage.

The loss of interplay between CD200-CD200R will induce microglial proliferation and activation that may exacerbate the process of neuroinflammation and aggravate the prognosis after stroke, as has been shown in a recent study conducted on CD200R1 knock-out mice, in which more deaths took place commensurate to the group of wild-type mice, probably because this induces monocyte infiltration and microgliosis [20].

Consequently, CD200 could play an important role in therapeutic strategies for the treatment of ischemic stroke by way of the inhibition of detrimental leukocyte activation and improvement of stroke-induced lymphopenia.

\subsection{The Role of Astrocytes Activation in Neuroinflammation}

Astrocytes are not only simple structural cells but are implicated in cerebral physiological and pathological processes such as neuroinflammation.

Evidence suggested that glial glutamate transporter (which acronym is GLT-1), an astrocytes' transporter, after a brain ischemic event, could be responsible for opposite consequences because it takes up glutamate and consequently performing neuroprotective effects in the initial phases of ischemia. It is also capable of lengthening the ischemic damage because it issues glutamate and affects neuronal cells irreversibly until their death [21]. Astrogliosis is liable for changes in terms of morphology and function. Indeed, it determines the formation of a glial scar which has a neuroprotective role because it safeguards salubrious tissues from damages attributable to inflammation, allowing to restrict lesion size, but also may reduce infarct area recovery by diminish axons regeneration and preventing neuroplasticity [22]. Many molecules like p53 [104], p38 mitogen-activated protein kinase [105], acute-phase protein pentraxin-3 [106], and CD36 are implicated in astrocytes activation.

Consideration the assessments mentioned above, targeting astrocytes may represent an effective therapeutic strategy because, by extending livelihood of these cells, after an ischemic insult, it is possible to prolong neuronal continued-existence.

Indeed, $\mathrm{Xu}$ et al. demonstrated that astrocyte resistance is augmented determining an overexpression of superoxide dismutase-2 and HSP-72 (the acronym of heat shock protein 72). Through this mechanism, it is possible to preserve CA1 pyramidal neurons after a cerebrovascular accident involving the prosencephalon [107]. In the same way, pyruvate, increasing the production of glutathione, an antioxidant molecule which defends cells from toxicant agents like ROS, reduce injurious effects of glutamate activity in a heterogeneous culture of cortical cells $[106,108]$. Other studies have shown that p53 avoids impaired glutamate intake in astrocytes; consequently, it may be another therapeutic target in stroke lesion [104]. Some microRNAs expressed in astrocytes are also implicated in the physiopathologic mechanism of cerebral ischemia, therefore, by targeting them it is possible to ameliorate stroke outcome [109].

\section{The Role of the Adaptative Immune System in Neuroinflammation}

The term adaptative immunity (also known as acquired- or specific immunity) indicates an inflammatory response to pathological damage, and it includes some peculiar cell types called lymphocytes characterized by more effective and specific intervention, though at a slower pace, compared to the innate system against a pathogenic noxa.

The adaptive immune system could be dichotomously divided into humoral and cell-mediated immunity. 
After a cerebrovascular accident, a finding of $\mathrm{T}$ cell activation and circulating antibodies supports the hypothesis that these exponents of acquired immunity could play a significant part in the inflammatory milieu related to brain injury.

Lymphocytes constitute one of the most important subgroups of white blood cells because they activate microglia, determinate a cerebral infarction of leukocytes, and influence the releasing of cytokines. Therefore, they have a crucial impact on stroke pathophysiologic mechanisms and the neuroinflammatory outcome. As known from many studies, several subtypes of lymphocytes such as TH17, $\gamma \delta$ T-cells, and TH1 aggravate clinical prognosis, performing a pro-inflammatory activity, and the inhibition of their migration to the cerebral lesion allows to obtain better outcomes [110-112].

On the contrary, regulatory T-cells (also called Treg) have a neuroprotective role because they are capable of limiting disease [113]. The noxious effect of Treg depletion over the stroke size and outcomes have been investigated through a mechanism of cell lysis led by antibodies anti-CD25 [114]. Besides, for the same purpose, a study is conducted on transgenic mice with a receptor which binds the toxin of diphtheria (DTR) transgene. It is also used Foxp3 promoter for inducible Treg population reduction [115].

IL-33, Interleukin (IL)-2, T cell receptor recognition and serotonin promote the cerebral Treg cells proliferation, and the chemokines CCL1 and CCL20 are involved in the infiltration into the brain. Besides, as suggested by Ito et al. [116], in a recent experimental mice-model study, lymphocytes Treg in brain injury after stroke chronically regulate neurotoxic astrogliosis and neural rescue. They indeed release a ligand with low affinity for EGFR (the acronym of epidermal growth factor receptor) called amphiregulin.

Tuttolomondo et al. [117] analyzed the peripheral amount of a particular subcategory of T CD4+ lymphocytes which are defective for CD28 antigen in patients affected by ischemic brain injury considering the etiopathogenetic subset according to TOAST classification.

It has also been examined the relationship between CD28 null (also known as or CD4 + CD28cells) with the entity of clinical severity of the cerebrovascular event valued through specific scores and with clinical outcomes comparatively diagnostic subset. It has been found that, during the acute phase of post-stroke neuroinflammation, CD4+ and CD28 null populations are more numerically represented and significantly predominate when the etiopathogenesis of stroke is cardioembolic compared to lacunar or LAAS subcategory. These results highlighted the current correlation between augmented clinical severity, larger dimension of brain lesions in patients affected by cardioembolic stroke and the intensity of the inflammatory response.

Nakajima et al. investigated the role of Killer immunoglobulin-like receptors, also named with acronym KIRs), in some pathologies sharing a common feature of atherosclerotic pathological burden [118].

These receptors are capable of identifying the target of $\mathrm{T}$ cells and NK cells through the interplay with HLA (the acronym of Human leukocyte antigen) class I molecules.

Taking into relationship the linkage between KIRs and atherosclerosis, newsworthy research is conducted by Tuttolomondo et al. in order to investigate a possible role in the etiopathogenesis of an acute cerebrovascular event [119].

Indeed, after a cerebral ischemic injury, it has been found an increased expression of KIR genes which enhances the process of inflammation related to augmented blood levels of CD28null.

The findings mentioned above corroborate the theory of the capability of KIR genes of modulating the expression of corresponding protein receptors, boosting through the release of several cytokines and the triggering of NK and T cells the complex phenomenon of neuroinflammation.

\section{Relationship between Atrial Fibrillation and Neuroinflammation}

Atrial fibrillation is defined as an irregular supraventricular tachyarrhythmia, and it can be diagnosed using electrocardiogram heart tracing. It determines in patients affected a fivefold chance of cerebral ischemia as compared with a normal population [120]. 
It represents one of the most common causes of cardioembolic stroke, and the chance that this inauspicious event occurs is equal in patients suffering from permanent $\mathrm{AF}$ and in people affected by paroxysmal $\mathrm{AF}$, despite it, is frequently asymptomatic.

Therefore, concerning major risk to which people are suffering from the arrhythmia above-mentioned when its clinical presentation is without symptoms, it is absolutely necessary to discover a biomarker which can predict hopefully the probability that paroxysmal atrial fibrillation occurs.

Notwithstanding it has not yet be recognized as an index that meets all the requirements (high specific and sensible, inexpensive, high predictive, and rapid marker), several investigations are led on this issue.

Some of these studies have the purpose of molecules involved in the mechanism of fibrosis like MMP-9 (matrix metalloproteinase-9), Gal-3 (galectin 3), TGF- $\beta$, and PIIINP (the amino-terminal peptide of type III procollagen) [121-123].

Significant findings suggest an interesting correlation between the expression level of the molecules aforementioned and left atrial volume index (as known as LAVI), an effective predictor for the occurrence of atrial fibrillation.

Furthermore, serum concentrations of MMP-9, Gal-3 and PIIINP are found to be higher in people affected by atrial fibrillation, and that makes them possible upcoming predictors, in contrast to TGF- $\beta$ with which it has not discovered a significative relationship with the arrhythmia concerned.

Other researches focused their attention on neurohormonal aspects in the context of atrial fibrillation, especially on atrial natriuretic peptides like NT-pro-BNP and BNP.

Interesting evidence of a study led by Naya et al. [124] indicates a relevant increment of levels of BNP and NTproBNP and a decrease of left atrial appendage flow in patients that undergo cardioembolic stroke. On this basis, these benchmarks could be helpful to distinguish cardioembolic from non-cardioembolic brain injury already from the first days.

Rodriguez-Yanez et al. recruited patients with cryptogenic stroke, and they have shown increased not only levels of NT-pro-BNP and BNP in these subjects but also a conjunction between this and higher significative chance to develop atrial fibrillation [125].

Up-to-date investigations have shown that, from a physiopathological point of view, cerebral cardioembolism is closely related to a condition of systemic inflammation [126].

Regarding possible inflammation markers, recent researches have described the usefulness of neutrophil-to-lymphocyte ratio (which acronym is NLR) in the role of a predictive marker of thromboembolic stroke in patients affected by atrial fibrillation [127,128].

A study lead by Nakase et al. has estimated the blood concentration of inflammatory mediators in the occasion of the acute phase of ischemic injury. In the present case, have been found elevated levels of hsCRP (high-sensitivity C-reactive protein), TNF $\alpha$ and IL-6, especially of the first molecule mentioned. Consequently, the hsCRP could be employed as an index of endothelial dysfunction in patients afflicted by atrial fibrillation [129].

In another research performed by Tuttolomondo et al. [130,131] on patients belonging to different pathological subcategories according to the classification TOAST, an increment of hematic levels of some inflammatory cytokines such as IL-1, TNF $\alpha$, and IL-6 is observed in people members of CEI category compared to all the other ones.

Moreover, they expressed increased levels of vWF (von Willebrand factor) and more severe neurological impairment associated with an ominous prognosis.

All these scientific data found in literature denote the most severe entity of inflammation in patients with a cardioembolic stroke, and it is desirable leading further studies on this issue going forward to delineate new biomolecules which act as predictors of neuroinflammation, allowing to prevent subsequent brain injury. 


\section{Neuroinflammation and BBB Dysfunction}

The blood-brain-barrier (also termed BBB) is defined as a membrane characterized by a refined selective permeability. Its complex structure is composed of different cell types including pericytes, proteins forming part of the extracellular matrix, endothelial cells, and astrocytes end-feet.

The cerebral homeostasis is maintained thanks to the selective transition of hematic substances through tight junctions between endothelial cells [132].

The rupture and the consequential dysfunction of BBB plays a crucial role in the process of neuroinflammation after an acute cerebrovascular accident, promoting poor prognosis. Indeed, the pathological passage of inflammatory mediators, toxins, and several cell types belonged to the immune system, provokes a major chance of hemorrhagic transformation of the infarctual lesion and an increment of vasogenic edema with resultant higher mortality [133].

Microglial can activate NADPH oxidase and as a result increasing the production of ROS, disrupting blood-brain-barrier [134] and mediates pro-cytokines' secretion like interleukin (I.L.)1 $\beta$ and tumor necrosis factor (TNF- $\alpha$ ) [135]. When ischemia provokes brain injury and BBB dysfunction, metalloproteinases, particularly MMP-2 and MMP-9 activated by microglia, degrade basal laminal components, and tight junctions [136], exacerbating focal cerebral ischemic lesion [137].

In order to investigate the biochemical mechanism that underlies the BBB rupture, different studies focused on the role of some miRNAs.

Indeed, among a variety of microRNAs are involved in pathophysiologic mechanisms such as angiogenesis, vascular inflammation, and atherosclerosis. Rom et al. identified let-7g and microRNA-98, two well-preserved miRNAs implicated in neuroinflammation since their expression is regulated by GSK3 $\beta$ inhibition [138].

GSK3 $\beta$, also known as Glycogen synthase kinase $3 \beta$, is a multipurpose Serine/Threonine specific protein kinase identified in eukaryotic cells, which modulates the function of over 50 substrates through their phosphorylation. It takes part in plenty of fundamental cell activities, among other things, apoptosis, cell-cycle control, glycogen metabolism, cell differentiation, adhesion and motility, microtubule function, embryonic development, and inflammation [139]. It determines the impermeability of BBB in physiologic conditions, reduces the secretion of cytokines and other molecules involved in neuroinflammation in brain microvascular endothelial cells (BMVEC), has a safeguarding role against monocyte-endothelial interactions that induce BBB to break up and decreases monocyte adhesion to/migration across the BBB $[140,141]$. The Glycogen synthase kinase $3 \beta$ is one of the factors involved in the endothelial dysfunction, that represents the first physiopathological step of vascular damage caused by inflammation $[139,142]$. The inhibition of GSK3 $\beta$ could play a prominent anti-inflammatory and BBB-protective role. Targeting GSK3 $\beta$ itself might provoke too side effects, as being involved in numerous physiological processes. Therefore, a solution can be represented by the regulation of miRNA expression.

In this study, Rom et al. suggested that elevated expression levels of the GSK3 $\beta$ inhibitor-dependent microRNAs, such as let-7g and miR-98, could prevent the adhesion of white blood cells and their migration across the blood-brain-barrier, whether with in vivo either with in vitro approaches [138]. These findings are very significant because not many microRNAs had equivalent capabilities to ameliorate the function of blood-brain-barrier in vitro. Indeed, micro-RNA let-7g markedly prevent the adhesion of leukocytes, but not their migration and its action are empowered by microRNA-98.

Two monocyte chemotactic proteins called RANTES/CCL5 and protein-1/CCL2 play a significant part in neuroinflammation since they rule the process of chemotaxis of white blood cells, and they allow them to cross the blood-brain-barrier [143]. Protein-1/CCL2 enhances small Rho GTPases, and this action determines the rearrangement of actin which constitutes the cytoskeleton and the formation of stress fiber. It also induces the reallocation of tight junction proteins such as occludin, claudin-5, ZO-1, and ZO-2 [144]. In this way, the monocyte chemotactic protein above mentioned is responsible for the modification of the tightness of blood-brain-barrier. To impede the release of RANTES/CCL5 and MCP-1/CCL2, cells of the endothelium are treated with GSK3 $\beta$ inhibitors [145]. 
Therefore, modulating the expression of let-7g and microRNA-98, it is possible to decrease the blood levels of the cytokines aforesaid and to neutralize the harmful consequences on proteins which constitute tight junctions and actin, likewise decreasing the interplay between endothelial cells and white cells.

Even though numerous researches have been carried out on physiopathogenetic mechanisms of BBB leakage, it is not entirely explained which molecules mediate this process in ischemic stroke.

In this regard, Liao et al., in an interesting study published in March 2020, analyzed the potential role of A-FABP, the acronym of adipocyte fatty acid-binding protein. It is an adipokine especially expressed in endothelial cells, adipocytes, and macrophages which exerts a proinflammatory action, determining metabolic dysfunction [146-148].

Previous studies have described increased serum levels of A-FABP in diabetic, obese, and hypertensive patients, therefore affected by factors of risk of a cerebral ischemic event [149] and they have also shown a link between these increased levels and an augmented serum expression of hsCRP [150], well-known inflammation index, which is increased in a cerebrovascular accident.

Liao et al. [151] experimented by recourse of knock-out and wild-type mice for expression of A-FABP gene submitted to a procedure of occlusion of the middle cerebral artery (MCAO). They described higher blood and intraparenchymal expression of this gene in wild-type mice. Besides, in knock-out mice a significative reduction of infarct size and entity of vasogenic edema with substantial alleviation of clinical neurological manifestations take place, suggesting a possible role of A-FABP in the pathogenesis of ischemic brain injury. Indeed, in mice with higher levels of this adipokine, they observed enhanced transcription of MMP-9 by resident microglia, and peripheral macrophages through the activation of JNK-Jun pathway, responsible for the deterioration of tight junctions and subsequential BBB leakage.

Moreover, the genetic and pharmacological modulation of A-FABP could represent a promising therapeutic strategy, inhibiting its action of BBB demolition related to MMP-9 hyperactivation, and, consequently, relieving ischemic damage.

\section{6. miRNAs and Neuroinflammation}

In the last decenniums, it has been identified as a new subset of small non-coding RNAs called microRNAs or miRs. They are short sequences of 20-24 nucleotides of single-stranded non-coding RNA implicated in the regulation of endothelial dysfunction and cancer angiogenesis, silencing the expressions of the genes involved in these processes [152], but also in inflammatory, metabolic, neurodegenerative, and immunity phenomena.

Since it is possible to seek out microRNAs in different human biologic fluids like the serum, plasma, cerebrospinal fluid, and urine, numerous studies have the purpose to evaluating possible role as diagnostic and therapeutic markers of this sequences in different pathologies, including ischemic stroke [153].

These studies have shown that the expression miRNA-126, miRNA-124-3p, miRNA30a, and miRNA16 e let-7b are considerably elevated in patients with an acute ischemic brain lesion, but they are not employed with success in clinical routine [153,154].

In pioneering research led by Wang et al. in patients suffering from ischemic stroke, were discovered targets of miRNA382-5p, miRNA 221-3p, and miRNA-4271. They are respectively DNA topoisomerase I (TOP1; it modulates and modifies DNA strands during transcription), alpha-receptor of GABA (GABRA 1; which transmits cerebral inhibitory cues) and a beta-containing ubiquitin-protein ligase (BTRC; it is responsible for the demolition of CD4 after the interplay between HIV-1p). Other studies have demonstrated that miRNA-382-5p has the target of NFIA, the acronym of nuclear factor IA which is implied in the modulation of cholesterol metabolism and inflammatory response [21]; PGC-1a as known as peroxisome proliferator-activated receptor $\gamma$ coactivator $1 \mathrm{a}$, that mediates the pathogenetic process of atherosclerosis [155]. Besides, they described APOC3, also called apolipoprotein C-III, which is a direct target of mRNA-4271 that regulates serum concentrations of triglycerides [156]. 
Therefore, these miRNAs have all targets involved in etiopathogenetic substrates of ischemic injury.

A further study published in 2017, Wang et al. have revealed that in subjects suffered a stroke compared to normal people, the serum expression of miRNA-382-5p and miRNA-221-3p are significantly reduced, proposing a possible role in the quality of non-invasive diagnostic marker of stroke [157].

Other researches have suggested a relationship between the microRNA-3845p and various disease which share the same pathologic substrate of ischemia like atherosclerosis and ischemia of myocardium $[158,159]$. Additionally, a current investigation has shown that expression levels of microRNA-384-5p are lower in murine cells of ischemic myocardium and ventricular cells in hypoxic conditions [160]. Furthermore, considering the role of specific microRNAs in the regulation of ischemic disease, they could open a new health direction to improve prophylaxis and modify clinical outcomes after an ischemic brain injury [161]. Indeed, some studies have reported that miR-137 safeguards neurons against impairment related to reperfusion and ischemia modulating the Notch signaling cascade [162]. The Notch receptor engages itself to DLL4, the acronym of Delta-like ligand 4 . When the expression level of this ligand is elevated, the Notch signaling cascade is activated, and this impedes the sprouting of endothelial cells during the growth of blood vessels [163].

Several determinants like molecular modulators in the initial phase of embryogenesis, Notch receptors and downstream signaling patterns influence the regulation of the angiogenesis process by the Notch signaling pathway.

Different molecules mediate the process of angiogenesis. Among all of them, DLL4, a Notch ligand with high specificity for this receptor of endothelial progenitor cells, has a significant impact on vessel development [164,165]. Jia Fan et al., in an up-to-date analysis about microRNA-384-5p supposed that it could be involved in the pathogenesis of cerebral ischemic event because it influences the activation of DDL4 and, consequently, the process of angiogenesis [145].

They showed that the therapeutic use of microRNA-3845p mimics and small interference RNA Delta-like ligand 4 (also known as si-DLL4) in mice in which is realized a middle cerebral artery occlusion, reduce the extension of lesion, decreasing the populations of necrotic and karyopyknotic the number of and necrotic cortical cells, and is responsible for lower expression levels of VEGF protein and CD31. Therefore, other researches have underlined that another small non-coding-RNA called miRNA-181b can prevent the cleavage of caspase-3, reducing the entity of loss of neurons in the cerebral ischemic cortex, by attenuating neurological loss of function of mice after the realization of middle cerebral artery occlusion [166].

Moreover, microRNA-384-5p may constitute an innovative approach for the therapy of cerebral ischemic stroke because it modulates angiogenesis and proliferation of endothelial progenitor cells and prevents neuronal apoptosis from interacting with DDL4 in the Notch signaling pathway.

\section{Conclusions}

Brain ischemic injury represents the second most frequent reason for death and long term disablement throughout the world. From the etiopathogenic point of view, TOAST classification has described several stroke subtypes. They could be large-artery atherosclerosis, cardioembolism, systemic hypoperfusion, penetrating artery disease, carotid dissection, hypercoagulability of genetic syndromes or with an undetermined etiology. By which, atherosclerosis formation has been blamed to be one of the culprits for the inclining cases of stroke-related death.

Therefore, atherosclerosis acts like the trigger of an intricate chain of events which modify molecular, genomic and cellular frameworks and inflammation has a pivotal role in this cascade, both in the central and in the peripheric nervous system. After an ischemic stroke, several cytokines take part in neuroinflammation, and their actions have repercussions on increasing infarct size, brain impairment, and clinical prognosis. Clinical findings have evidence that, in the acute phase, it is essential preventing deleterious effects of mediators of neuroinflammation to avoid poor outcomes. 
Considering these assessments, in recent years, many authors have investigated the role of several molecules involved in atherosclerosis to identify innovatory biomarkers which are the expression of worsening outcomes. In this way, patients who have more substantial death and disability risk may be subject to frequent and accurate monitoring and appropriate therapeutic protocols.

Moreover, it could be auspicious that future studies will contribute to the detection and the comprehending of an increasing number of genetic, biological, and molecular key factors of stroke, in term of predisposition to the disease, establishment, and progression of the damage. The results of these studies could, in future, lay the cornerstone for identification of new therapeutic targets that may allow a significant modification of death and disability rate.

Funding: This research received no external funding.

Conflicts of Interest: The authors declare no conflict of interest.

\section{Abbreviations}

\begin{tabular}{|c|c|}
\hline A-FABP & Adipocyte fatty acid-binding protein \\
\hline $\mathrm{AF}$ & Atrial fibrillation \\
\hline ApoE & Apolipoprotein E \\
\hline ApoC3 & Apolipoprotein C-III \\
\hline ASC & Apoptosis-associated speck-like protein containing a CARD \\
\hline BBB & Blood-brain barrier \\
\hline BTRC & Beta-transducin repeat containing \\
\hline CCL1 & Chemokine (C-C motif) ligand 1 \\
\hline CCL5 & Chemokine (C-C motif) ligand 5 \\
\hline CCL20 & Chemokine (C-C motif) ligand 20 \\
\hline CCR5 & C-C chemokine receptor type 5 \\
\hline CLEC2 & C-type lectin-like receptor 2 \\
\hline CLEC9A & C-type lectin-like receptor $9 \mathrm{~A}$ \\
\hline COX-2 & Cyclooxygenase-2 \\
\hline CSF-3 & Colony-stimulating factor 3 \\
\hline CX3CL1 & Chemokine (C-X3-C motif) ligand 1 \\
\hline CXCL4 & Chemokine (C-X-C motif) ligand 4 \\
\hline CXCL7 & Chemokine (C-X-C motif) ligand 7 \\
\hline CXCL8 & Chemokine (C-X-C motif) ligand 8 \\
\hline DAMPs & Damage-associated molecular patterns \\
\hline DLL-4 & Delta-like ligand 4 \\
\hline DKK-3 & Dickkopf WNT Signaling Pathway Inhibitor 3 \\
\hline FOXP3 & Forkhead box P3 \\
\hline GABRA 1 & Alpha receptor GABA 1 \\
\hline Gal-3 & Galectin-3 \\
\hline GLT-1 & Glial glutamate transporter \\
\hline GSK3 $\beta$ & Glycogen synthase kinase 3 beta \\
\hline hemITAMs & Hemi-immunoreceptor tyrosine-based activation motifs \\
\hline hsCRP & High-sensitivity C-reactive protein \\
\hline HSP-72 & Heat shock protein 72 \\
\hline IL-1 $\alpha$ & Interleukin 1 alpha \\
\hline IL-1 $\beta$ & Interleukin 1 beta \\
\hline IL-6 & Interleukin \\
\hline IL-7 & Interleukin 7 \\
\hline IL-10 & Interleukin 10 \\
\hline IL-17 & Interleukin 17 \\
\hline IL-18 & Interleukin 18 \\
\hline IL-20 & Interleukin 20 \\
\hline IL-23 & Interleukin 23 \\
\hline
\end{tabular}




\begin{tabular}{|c|c|}
\hline iNOS & Inducible nitric oxide synthase \\
\hline IRF4 & Interferon regulatory factor 4 \\
\hline IRF5 & Interferon regulatory factor 5 \\
\hline IRS-1 & Insulin receptor substrate 1 \\
\hline ITAMs & Immunoreceptor tyrosine-based activation motifs \\
\hline JNK & c-Jun N-terminal kinase \\
\hline KIRs & Killer immunoglobulin-like receptors \\
\hline LAM & Laminarin \\
\hline LRR & Leucine-rich repeats \\
\hline Ly6C & Ly6Chi monocytes \\
\hline MCAO & Middle cerebral artery occlusion \\
\hline MiMథs & Microglia-derived macrophages \\
\hline miRNAs & MicroRNAs \\
\hline MoMФs & Monocyte-derived macrophages \\
\hline MPO & Myeloperoxidase \\
\hline MMP-9 & Matrix metalloproteinase 9 \\
\hline NADPH oxidase & Nicotinamide adenine dinucleotide phosphate oxidase \\
\hline NAIP & Neuronal apoptosis inhibitory protein \\
\hline NLR & NOD-like receptor \\
\hline NLR & Neutrophil-to-lymphocyte ratio \\
\hline NLRP3 & NLR family pyrin domain containing 3 \\
\hline NFIA & Nuclear factor IA \\
\hline PIC & Piceatannol \\
\hline PIIINP & Amino-terminal peptide of type III procollagen \\
\hline PGC-1a & Peroxisome proliferator-activated receptor $\gamma$ coactivator 1 \\
\hline PPAR- $\gamma$ & Peroxisome proliferator-activated receptor gamma \\
\hline PYCARD & PYD And CARD Domain Containing \\
\hline PYD & Pyrin domain \\
\hline ROS & Reactive oxygen species \\
\hline siRNA & Small interfering RNA \\
\hline SYK & Spleen tyrosine kinase \\
\hline TGF- $\beta$ & Transforming growth factor-beta \\
\hline TNF- $\alpha$ & Tumor Necrosis Factor-alpha \\
\hline TOP1 & DNA topoisomerase I \\
\hline Tregs & Regulatory T cells \\
\hline TXNIP & Thioredoxin-interacting protein \\
\hline VDUP-1 & Vitamin D3-upregulated protein-1 \\
\hline VEGF & Vascular endothelial growth factor \\
\hline vWF & von Willebrand factor \\
\hline Wnt & Wingless-related integration site \\
\hline
\end{tabular}

\section{References}

1. WHO. The Atlas of Heart Disease and Stroke. Available online: https://www.who.int/cardiovascular diseases/resources/atlas/en/ (accessed on 19 November 2020).

2. Lynch, J.R.; Blessing, R.; White, W.D.; Grocott, H.P.; Newman, M.F.; Laskowitz, D.T. Novel diagnostic test for acute stroke. Stroke 2004, 35, 57-63. [CrossRef] [PubMed]

3. Meisel, C.; Schwab, J.M.; Prass, K.; Meisel, A.; Dirnagl, U. Central nervous system injury-induced immune deficiency syndrome. Nat. Rev. Neurosci. 2005, 6, 775-786. [CrossRef] [PubMed]

4. Urra, X.; Cervera, A.; Villamor, N.; Planas, A.M.; Chamorro, A. Harms and benefits of lymphocyte subpopulations in patients with acute stroke. Neuroscience 2009, 158, 1174-1183. [CrossRef] [PubMed]

5. Iadecola, C.; Anrather, J. The immunology of stroke: From mechanisms to translation. Nat. Med. 2011, 17, 796-808. [CrossRef] 
6. Weiner, H.L.; Selkoe, D.J. Inflammation and therapeutic vaccination in CNS diseases. Nature 2002, 420, 879-884. [CrossRef]

7. Tuttolomondo, A.; Maida, C.; Pinto, A. Inflammation and Inflammatory Cell Recruitment in Acute Cerebrovascular Diseases. Available online: https:/www.eurekaselect.com/130447/article (accessed on 19 November 2020).

8. Mayer, A.M.S.; Clifford, J.A.; Aldulescu, M.; Frenkel, J.A.; Holland, M.A.; Hall, M.L.; Glaser, K.B.; Berry, J. Cyanobacterial Microcystis aeruginosa lipopolysaccharide elicits release of superoxide anion, thromboxane $\mathrm{B}_{2}$, cytokines, chemokines, and matrix metalloproteinase-9 by rat microglia. Toxicol. Sci. 2011, 121, 63-72. [CrossRef]

9. Na, K.-S.; Jung, H.-Y.; Kim, Y.-K. The role of pro-inflammatory cytokines in the neuroinflammation and neurogenesis of schizophrenia. Prog. Neuropsychopharmacol. Biol. Psychiatry 2014, 48, 277-286. [CrossRef]

10. Ip, C.W.; Kroner, A.; Groh, J.; Huber, M.; Klein, D.; Spahn, I.; Diem, R.; Williams, S.K.; Nave, K.-A.; Edgar, J.M.; et al. Neuroinflammation by Cytotoxic T-Lymphocytes Impairs Retrograde Axonal Transport in an Oligodendrocyte Mutant Mouse. PLoS ONE 2012, 7, e42554.[CrossRef]

11. Pétrilli, V.; Dostert, C.; A Muruve, D.; Tschopp, J. The inflammasome: A danger sensing complex triggering innate immunity. Curr. Opin. Immunol. 2007, 19, 615-622. [CrossRef]

12. Tureyen, K.; Bowen, K.; Liang, J.; Dempsey, R.J.; Vemuganti, R. Exacerbated brain damage, edema and inflammation in type-2 diabetic mice subjected to focal ischemia. J. Neurochem. 2011, 116, 499-507. [CrossRef]

13. Cheng, W.; Yang, Y.; Zhang, X.; Guo, J.; Gong, J.; Gong, F.; She, Z.; Huang, Z.; Xia, H.; Li, H. Dickkopf-3 Ablation Attenuates the Development of Atherosclerosis in ApoE-Deficient Mice. J. Am. Heart Assoc. 2017, 6, e004690. [CrossRef] [PubMed]

14. Monaghan, A.; Kioschis, P.; Wu, W.; Zuniga, A.; Bock, D.; Poustka, A.; Delius, H.; Niehrs, C. Dickkopf genes are co-ordinately expressed in mesodermal lineages. Mech. Dev. 1999, 87, 45-56. [CrossRef]

15. Ye, X.; Hao, Q.; Ma, W.-J.; Zhao, Q.-C.; Wang, W.-W.; Yin, H.-H.; Zhang, T.; Wang, M.; Zan, K.; Yang, X.-X.; et al. Dectin-1/Syk signaling triggers neuroinflammation after ischemic stroke in mice. J. Neuroinflamm. 2020, 17, 1-16. [CrossRef] [PubMed]

16. Koenen, R.R.; Von Hundelshausen, P.; Nesmelova, I.V.; Zernecke, A.; Liehn, E.A.; Sarabi, A.; Kramp, B.K.; Piccinini, A.M.; Paludan, S.R.; Kowalska, M.A.; et al. Disrupting functional interactions between platelet chemokines inhibits atherosclerosis in hyperlipidemic mice. Nat. Med. 2009, 15, 97-103. [CrossRef]

17. Terao, S.; Yilmaz, G.; Stokes, K.Y.; Russell, J.; Ishikawa, M.; Kawase, T.; Granger, D.N. Blood Cell-Derived RANTES Mediates Cerebral Microvascular Dysfunction, Inflammation, and Tissue Injury After Focal Ischemia-Reperfusion. Stroke 2008, 39, 2560-2570. [CrossRef]

18. Günthner, R.; Anders, H.-J. Interferon-Regulatory Factors Determine Macrophage Phenotype Polarization. Mediat. Inflamm. 2013, 2013, 1-8. [CrossRef]

19. Al Mamun, A.; Chauhan, A.; Yu, H.; Xu, Y.; Sharmeen, R.; Liu, F. Interferon regulatory factor $4 / 5$ signaling impacts on microglial activation after ischemic stroke in mice. Eur. J. Neurosci. 2018, 47, 140-149. [CrossRef]

20. Ritzel, R.M.; Patel, A.R.; Grenier, J.M.; Crapser, J.; Verma, R.; Jellison, E.R.; McCullough, L.D. Functional differences between microglia and monocytes after ischemic stroke. J. Neuroinflamm. 2015, 12, 1-12. [CrossRef]

21. Mitani, A.; Tanaka, K. Functional changes of glial glutamate transporter GLT-1 during ischemia: An in vivo study in the hippocampal CA1 of normal mice and mutant mice lacking GLT-1. J. Neurosci. 2003, 23, 7176-7182. [CrossRef]

22. Pekny, M.; Wilhelmsson, U.; Pekna, M. The dual role of astrocyte activation and reactive gliosis. Neurosci. Lett. 2014, 565, 30-38. [CrossRef]

23. Schroder, K.; Tschopp, J. The inflammasomes. Cell 2010, 140, 821-832. [CrossRef] [PubMed]

24. Dinarello, C.A. Immunological and inflammatory functions of the interleukin-1 family. Annu. Rev. Immunol. 2009, 27, 519-550. [CrossRef] [PubMed]

25. Niu, L.; Zhang, S.; Wu, J.; Chen, L.; Wang, Y. Data from: Upregulation of NLRP3 inflammasome in the tears and ocular surface of dry eye patients. PLoS ONE 2015, 10, e0126277. [CrossRef] [PubMed]

26. Ting, J.P.-Y.; Lovering, R.C.; Alnemri, E.S.; Bertin, J.; Boss, J.M.; Davis, B.K.; Flavell, R.A.; Girardin, S.E.; Godzik, A.; Harton, J.A.; et al. The NLR gene family: A standard nomenclature. Immunity 2008, 28, 285-287. [CrossRef]

27. Dostert, C.; Pétrilli, V.; Bruggen, R.V.; Steele, C.; Mossman, B.T.; Tschopp, J. Innate Immune Activation Through Nalp3 Inflammasome Sensing of Asbestos and Silica. Science 2008, 320, 674-677. [CrossRef] 
28. Schroder, K.; Zhou, R.; Tschopp, J. The NLRP3 inflammasome: A sensor for metabolic danger? Science 2010, 327, 296-300. [CrossRef]

29. Yang, F.; Wang, Z.; Wei, X.; Han, H.; Meng, X.; Zhang, Y.; Shi, W.; Li, F.; Xin, T.; Pang, Q.; et al. NLRP3 deficiency ameliorates neurovascular damage in experimental ischemic stroke. J. Cereb. Blood Flow Metab. 2014, 34, 660-667. [CrossRef]

30. Gao, L.; Dong, Q.; Song, Z.; Shen, F.; Shi, J.; Li, Y. NLRP3 inflammasome: A promising target in ischemic stroke. Inflamm. Res. 2017, 66, 17-24. [CrossRef]

31. Kousathana, F.; Georgitsi, M.; Lambadiari, V.; Giamarellos-Bourboulis, E.J.; Dimitriadis, G.; Mouktaroudi, M. Defective production of interleukin-1 beta in patients with type 2 diabetes mellitus: Restoration by proper glycemic control. Cytokine 2017, 90, 177-184. [CrossRef]

32. Wolf, A.J.; Reyes, C.N.; Liang, W.; Becker, C.; Shimada, K.; Wheeler, M.L.; Cho, H.C.; Popescu, N.I.; Coggeshall, K.M.; Arditi, M.; et al. Hexokinase Is an Innate Immune Receptor for the Detection of Bacterial Peptidoglycan. Cell 2016, 166, 624-636. [CrossRef]

33. Zhou, R.; Yazdi, A.S.; Menu, P.; Tschopp, J. A role for mitochondria in NLRP3 inflammasome activation. Nature 2011, 469, 221-225. [CrossRef] [PubMed]

34. Wang, Q.; Tang, X.N.; Yenari, M.A. The inflammatory response in stroke. J. Neuroimmunol. 2007, 184, 53-68. [CrossRef] [PubMed]

35. Minutoli, L.; Puzzolo, D.; Rinaldi, M.; Irrera, N.; Marini, H.; Arcoraci, V.; Bitto, A.; Crea, G.; Pisani, A.; Squadrito, F.; et al. ROS-Mediated NLRP3 Inflammasome Activation in Brain, Heart, Kidney, and Testis Ischemia/Reperfusion Injury. Available online: https:/www.hindawi.com/journals/omcl/2016/2183026/ (accessed on 19 November 2020).

36. Vandanmagsar, B.; Youm, Y.-H.; Ravussin, A.; Galgani, J.E.; Stadler, K.; Mynatt, R.L.; Ravussin, E.; Stephens, J.M.; Dixit, V.D. The NLRP3 inflammasome instigates obesity-induced inflammation and insulin resistance. Nat. Med. 2011, 17, 179-188. [CrossRef] [PubMed]

37. Oslowski, C.M.; Hara, T.; O’Sullivan-Murphy, B.; Kanekura, K.; Lu, S.; Hara, M.; Ishigaki, S.; Zhu, L.J.; Hayashi, E.; Hui, S.T.; et al. Thioredoxin-interacting protein mediates ER stress-induced $\beta$ cell death through initiation of the inflammasome. Cell Metab. 2012, 16, 265-273. [CrossRef]

38. Hou, Y.; Wang, Y.; He, Q.; Li, L.; Xie, H.; Zhao, Y.; Zhao, J. Nrf2 inhibits NLRP3 inflammasome activation through regulating Trx1/TXNIP complex in cerebral ischemia reperfusion injury. Behav. Brain Res. 2018, 336, 32-39. [CrossRef] [PubMed]

39. Mizobuchi, Y.; Matsuzaki, K.; Kuwayama, K.; Kitazato, K.; Mure, H.; Kageji, T.; Nagahiro, S. REIC/Dkk-3 induces cell death in human malignant glioma. Neuro-Oncology 2008, 10, 244-253. [CrossRef]

40. Lee, E.-J.; Jo, M.; Rho, S.B.; Park, K.; Yoo, Y.-N.; Park, J.; Chae, M.; Zhang, W.; Lee, J.-H. Dkk3, downregulated in cervical cancer, functions as a negative regulator of beta-catenin. Int. J. Cancer 2009, 124, 287-297. [CrossRef]

41. Peifer, M.; Polakis, P. Wnt signaling in oncogenesis and embryogenesis-A look outside the nucleus. Science 2000, 287, 1606-1609. [CrossRef]

42. Yu, B.; Kiechl, S.; Qi, D.; Wang, X.; Song, Y.; Weger, S.; Mayr, A.; Le Bras, A.; Karamariti, E.; Zhang, Z.; et al. A Cytokine-Like Protein Dickkopf-Related Protein 3 Is Atheroprotective. Circulation 2017, 136, 1022-1036. [CrossRef]

43. Caricasole, A.; Ferraro, T.; Iacovelli, L.; Barletta, E.; Caruso, A.; Melchiorri, D.; Terstappen, G.C.; Nicoletti, F. Functional characterization of WNT7A signaling in PC12 cells: Interaction with A FZD5 x LRP6 receptor complex and modulation by Dickkopf proteins. J. Biol. Chem. 2003, 278, 37024-37031. [CrossRef]

44. Kim, B.-R.; Lee, E.-J.; Seo, S.H.; Lee, S.-H.; Rho, S.B. Dickkopf-3 (DKK-3) obstructs VEGFR-2/Akt/mTOR signaling cascade by interacting of $\beta 2$-microglobulin $(\beta 2 \mathrm{M})$ in ovarian tumorigenesis. Cell Signal. 2015, 27, 2150-2159. [CrossRef]

45. Chen, T.; Karamariti, E.; Hong, X.; Deng, J.; Wu, Y.; Gu, W.; Simpson, R.; Wong, M.M.; Yu, B.; Hu, Y.; et al. DKK3 (Dikkopf-3) Transdifferentiates Fibroblasts Into Functional Endothelial Cells—Brief Report. Arterioscler. Thromb. Vasc. Biol. 2019, 39, 765-773. [CrossRef]

46. He, J.; Zhang, Y.; Xu, T.; Zhao, Q.; Wang, D.; Chen, C.-S.; Tong, W.; Liu, C.; Xu, T.; Ju, Z.; et al. Effects of immediate blood pressure reduction on death and major disability in patients with acute ischemic stroke: The CATIS randomized clinical trial. JAMA 2014, 311, 479-489. [CrossRef] 
47. Abulafia, D.P.; de Rivero Vaccari, J.P.; Lozano, J.D.; Lotocki, G.; Keane, R.W.; Dietrich, W.D. Inhibition of the inflammasome complex reduces the inflammatory response after thromboembolic stroke in mice. J. Cereb. Blood Flow Metab. 2009, 29, 534-544. [CrossRef]

48. Jung, J.E.; Kim, G.S.; Chan, P.H. Neuroprotection by interleukin-6 is mediated by signal transducer and activator of transcription 3 and antioxidative signaling in ischemic stroke. Stroke 2011, 42, 3574-3579. [CrossRef]

49. Poltorak, A.; He, X.; Smirnova, I.; Liu, M.Y.; Van Huffel, C.; Du, X.; Birdwell, D.; Alejos, E.; Silva, M.; Galanos, C.; et al. Defective LPS signaling in $\mathrm{C} 3 \mathrm{H} / \mathrm{HeJ}$ and C57BL/10ScCr mice: Mutations in Tlr4 gene. Science 1998, 282, 2085-2088. [CrossRef]

50. Tang, S.-C.; Arumugam, T.V.; Xu, X.; Cheng, A.; Mughal, M.R.; Jo, D.G.; Lathia, J.D.; Siler, D.A.; Chigurupati, S.; Ouyang, X.; et al. Pivotal role for neuronal Toll-like receptors in ischemic brain injury and functional deficits. Proc. Natl. Acad. Sci. USA 2007, 104, 13798-13803. [CrossRef]

51. Shichita, T.; Hasegawa, E.; Kimura, A.; Morita, R.; Sakaguchi, R.; Takada, I.; Sekiya, T.; Ooboshi, H.; Kitazono, T.; Yanagawa, T.; et al. Peroxiredoxin family proteins are key initiators of post-ischemic inflammation in the brain. Nat. Med. 2012, 18, 911-917. [CrossRef]

52. Willment, J.A.; Marshall, A.S.J.; Reid, D.M.; Williams, D.L.; Wong, S.Y.C.; Gordon, S.; Brown, G.D. The human beta-glucan receptor is widely expressed and functionally equivalent to murine Dectin-1 on primary cells. Eur. J. Immunol. 2005, 35, 1539-1547. [CrossRef]

53. Martin, B.; Hirota, K.; Cua, D.J.; Stockinger, B.; Veldhoen, M. Interleukin-17-producing gammadelta T cells selectively expand in response to pathogen products and environmental signals. Immunity 2009, 31, 321-330. [CrossRef]

54. Sun, W.-K.; Lu, X.; Li, X.; Sun, Q.-Y.; Su, X.; Song, Y.; Sun, H.-M.; Shi, Y. Dectin-1 is inducible and plays a crucial role in Aspergillus-induced innate immune responses in human bronchial epithelial cells. Eur. J. Clin. Microbiol. Infect. Dis. 2012, 31, 2755-2764. [CrossRef] [PubMed]

55. Bertuzzi, M.; Schrettl, M.; Alcazar-Fuoli, L.; Cairns, T.C.; Muñoz, A.; Walker, L.A.; Herbst, S.; Safari, M.; Cheverton, A.M.; Chen, D.; et al. The pH-responsive PacC transcription factor of Aspergillus fumigatus governs epithelial entry and tissue invasion during pulmonary aspergillosis. PLoS Pathog. 2014, 10, e1004413. [CrossRef] [PubMed]

56. Reid, D.M.; Montoya, M.; Taylor, P.R.; Borrow, P.; Gordon, S.; Brown, G.D.; Wong, S.Y.C. Expression of the beta-glucan receptor, Dectin-1, on murine leukocytes in situ correlates with its function in pathogen recognition and reveals potential roles in leukocyte interactions. J. Leukoc. Biol. 2004, 76, 86-94. [CrossRef] [PubMed]

57. Lech, M.; Susanti, H.E.; Römmele, C.; Gröbmayr, R.; Günthner, R.; Anders, H.-J. Quantitative expression of C-type lectin receptors in humans and mice. Int. J. Mol. Sci. 2012, 13, 10113-10131. [CrossRef] [PubMed]

58. Gross, O.; Poeck, H.; Bscheider, M.; Dostert, C.; Hannesschläger, N.; Endres, S.; Hartmann, G.; Tardivel, A.; Schweighoffer, E.; Tybulewicz, V.; et al. Syk kinase signalling couples to the Nlrp3 inflammasome for anti-fungal host defence. Nature 2009, 459, 433-436. [CrossRef] [PubMed]

59. Saïd-Sadier, N.; Padilla, E.; Langsley, G.; Ojcius, D.M. Aspergillus fumigatus stimulates the NLRP3 inflammasome through a pathway requiring ROS production and the Syk tyrosine kinase. PLoS ONE 2010, 5, e10008. [CrossRef]

60. Kankkunen, P.; Teirilä, L.; Rintahaka, J.; Alenius, H.; Wolff, H.; Matikainen, S. (1,3)-beta-glucans activate both dectin-1 and NLRP3 inflammasome in human macrophages. J. Immunol. 2010, 184, 6335-6342. [CrossRef]

61. Hise, A.G.; Tomalka, J.; Ganesan, S.; Patel, K.; Hall, B.A.; Brown, G.D.; Fitzgerald, K.A. An Essential Role for the NLRP3 Inflammasome in Host Defense against the Human Fungal Pathogen Candida albicans. Available online: https://pubmed.ncbi.nlm.nih.gov/19454352/ (accessed on 20 November 2020).

62. Gringhuis, S.I.; Kaptein, T.M.; Wevers, B.A.; Theelen, B.; van der Vlist, M.; Boekhout, T.; Geijtenbeek, T.B.H. Dectin-1 is an extracellular pathogen sensor for the induction and processing of IL-1 $\beta$ via a noncanonical caspase-8 inflammasome. Nat. Immunol. 2012, 13, 246-254. [CrossRef]

63. Gensel, J.C.; Wang, Y.; Guan, Z.; Beckwith, K.A.; Braun, K.J.; Wei, P.; McTigue, D.M.; Popovich, P.G. Toll-Like Receptors and Dectin-1, a C-Type Lectin Receptor, Trigger Divergent Functions in CNS Macrophages. Available online: https://pubmed.ncbi.nlm.nih.gov/26156997/ (accessed on 20 November 2020). 
64. Baldwin, K.T.; Carbajal, K.S.; Segal, B.M.; Giger, R.J. Neuroinflammation Triggered by $\beta$-glucan/dectin-1 Signaling Enables CNS Axon Regeneration. Available online: https:/pubmed.ncbi.nlm.nih.gov/25675510/ (accessed on 20 November 2020).

65. Turner, M.; Schweighoffer, E.; Colucci, F.; Di Santo, J.P.; Tybulewicz, V.L. Tyrosine kinase SYK: Essential functions for immunoreceptor signalling. Immunol. Today 2000, 21, 148-154. [CrossRef]

66. Riccaboni, M.; Bianchi, I.; Petrillo, P. Spleen Tyrosine Kinases: Biology, Therapeutic Targets and Drugs. Available online: https://pubmed.ncbi.nlm.nih.gov/20553955/ (accessed on 20 November 2020).

67. Duta, F.; Ulanova, M.; Seidel, D.; Puttagunta, L.; Musat-Marcu, S.; Harrod, K.S.; Schreiber, A.D.; Steinhoff, U.; Befus, A.D. Differential Expression of Spleen Tyrosine Kinase Syk Isoforms in Tissues: Effects of the Microbial Flora. Available online: https://pubmed.ncbi.nlm.nih.gov/16708245/ (accessed on 20 November 2020).

68. Friedrich, V.; Flores, R.; Muller, A.; Bi, W.; Peerschke, E.I.; Sehba, F.A. Reduction of neutrophil activity decreases early microvascular injury after subarachnoid haemorrhage. J. Neuroinflamm. 2011, 8, 103. [CrossRef]

69. Kim, J.Y.; Kawabori, M.; Yenari, M.A. Innate inflammatory responses in stroke: Mechanisms and potential therapeutic targets. Curr. Med. Chem 2014, 21, 2076-2097. [CrossRef] [PubMed]

70. Ystgaard, M.B.; Sejersted, Y.; Løberg, E.M.; Lien, E.; Yndestad, A.; Saugstad, O.D. Early Upregulation of NLRP3 in the Brain of Neonatal Mice Exposed to Hypoxia-Ischemia: No Early Neuroprotective Effects of NLRP3 Deficiency. Neonatology 2015, 108, 211-219. [CrossRef] [PubMed]

71. Kawai, T.; Akira, S. The role of pattern-recognition receptors in innate immunity: Update on Toll-like receptors. Nat. Immunol. 2010, 11, 373-384. [CrossRef] [PubMed]

72. Pamuk, O.N.; Lapchak, P.H.; Rani, P.; Pine, P.; Dalle Lucca, J.J.; Tsokos, G.C. Spleen tyrosine kinase inhibition prevents tissue damage after ischemia-reperfusion. Am. J. Physiol. Gastrointest. Liver Physiol. 2010, 299, G391-G399. [CrossRef]

73. Huysamen, C.; Willment, J.A.; Dennehy, K.M.; Brown, G.D. CLEC9A is a novel activation C-type lectin-like receptor expressed on BDCA3+ dendritic cells and a subset of monocytes. J. Biol. Chem. 2008, 283, 16693-16701. [CrossRef]

74. Yamasaki, S.; Ishikawa, E.; Sakuma, M.; Hara, H.; Ogata, K.; Saito, T. Mincle is an ITAM-coupled activating receptor that senses damaged cells. Nat. Immunol. 2008, 9, 1179-1188. [CrossRef]

75. Sancho, D.; Joffre, O.P.; Keller, A.M.; Rogers, N.C.; Martínez, D.; Hernanz-Falcón, P.; Rosewell, I.; e Sousa, C.R. Identification of a dendritic cell receptor that couples sensing of necrosis to immunity. Nature 2009, 458, 899-903. [CrossRef]

76. Yang, W.S.; Lee, J.; Kim, T.W.; Kim, J.H.; Lee, S.; Rhee, M.H.; Hong, S.; Cho, J.Y. Src/NF-kB-targeted inhibition of LPS-induced macrophage activation and dextran sodium sulphate-induced colitis by Archidendron clypearia methanol extract. J. Ethnopharmacol. 2012, 142, 287-293. [CrossRef]

77. Yu, T.; Lee, S.; Yang, W.S.; Jang, H.-J.; Lee, Y.J.; Kim, T.W.; Kim, S.Y.; Lee, J.; Cho, J.Y. The ability of an ethanol extract of Cinnamomum cassia to inhibit Src and spleen tyrosine kinase activity contributes to its anti-inflammatory action. J. Ethnopharmacol. 2012, 139, 566-573. [CrossRef]

78. Jeong, D.; Yang, W.S.; Yang, Y.; Nam, G.; Kim, J.H.; Yoon, D.H.; Noh, H.J.; Lee, S.; Kim, T.W.; Sung, G.-H.; et al. In vitro and in vivo anti-inflammatory effect of Rhodomyrtus tomentosa methanol extract. J. Ethnopharmacol. 2013, 146, 205-213. [CrossRef]

79. Yoon, J.Y.; Jeong, H.Y.; Kim, S.H.; Kim, H.G.; Nam, G.; Kim, J.P.; Yoon, D.H.; Hwang, H.; Kimc, T.W.; Hong, S.; et al. Methanol extract of Evodia lepta displays Syk/Src-targeted anti-inflammatory activity. J. Ethnopharmacol. 2013, 148, 999-1007. [CrossRef] [PubMed]

80. Mirabelli-Badenier, M.; Braunersreuther, V.; Viviani, G.L.; Dallegri, F.; Quercioli, A.; Veneselli, E.; Mach, F.; Montecucco, F. CC and CXC chemokines are pivotal mediators of cerebral injury in ischaemic stroke. Thromb. Haemost. 2011, 105, 409-420. [CrossRef] [PubMed]

81. Tuttolomondo, A.; Di Raimondo, D.; di Sciacca, R.; Pinto, A.; Licata, G. Inflammatory cytokines in acute ischemic stroke. Curr. Pharm. Des. 2008, 14, 3574-3589. [CrossRef] [PubMed]

82. Murphy, P.M.; Baggiolini, M.; Charo, I.F.; Hébert, C.A.; Horuk, R.; Matsushima, K.; Miller, L.H.; Oppenheim, J.J.; Power, C.A. International union of pharmacology. XXII. Nomenclature for chemokine receptors. Pharm. Rev. 2000, 52, 145-176. 
83. Vandercappellen, J.; Van Damme, J.; Struyf, S. The role of the CXC chemokines platelet factor-4 (CXCL4/PF-4) and its variant (CXCL4L1/PF-4var) in inflammation, angiogenesis and cancer. Cytokine Growth Factor Rev. 2011, 22, 1-18. [CrossRef]

84. Daly, T.J.; LaRosa, G.J.; Dolich, S.; Maione, T.E.; Cooper, S.; Broxmeyer, H.E. High Activity Suppression of Myeloid Progenitor Proliferation by Chimeric Mutants of Interleukin 8 and Platelet Factor 4. J. Biol. Chem. 1995, 270, 23282-23292. [CrossRef]

85. Gengrinovitch, S.; Greenberg, S.M.; Cohen, T.; Gitay-Goren, H.; Rockwell, P.; Maione, T.E.; Levi, B.Z.; Neufeld, G. Platelet factor-4 inhibits the mitogenic activity of VEGF121 and VEGF165 using several concurrent mechanisms. J. Biol. Chem. 1995, 270, 15059-15065. [CrossRef]

86. Crisi, G.M.; Katz, I.R.; Zucker, M.B.; Thorbecke, G.J. Induction of inhibitory activity for B cell differentiation in human CD8 T cells with pokeweed mitogen, dimaprit, and cAMP upregulating agents: Countersuppressive effect of platelet factor 4. Cell Immunol. 1996, 172, 205-216. [CrossRef]

87. Katayama, H.; Yokoyama, A.; Kohno, N.; Sakai, K.; Hiwada, K.; Yamada, H.; Hirai, K. Production of eosinophilic chemokines by normal pleural mesothelial cells. Am. J. Respir. Cell Mol. Biol. 2002, 26, 398-403. [CrossRef]

88. Aldinucci, D.; Colombatti, A. The inflammatory chemokine CCL5 and cancer progression. Mediat. Inflamm. 2014, 2014, 292376. [CrossRef]

89. Fan, Y.; Xiong, X.; Zhang, Y.; Yan, D.; Jian, Z.; Xu, B.; Zhao, H. MKEY, a Peptide Inhibitor of CXCL4-CCL5 Heterodimer Formation, Protects Against Stroke in Mice. J. Am. Heart Assoc. 2016, 5. [CrossRef] [PubMed]

90. Rayasam, A.; Hsu, M.; Kijak, J.A.; Kissel, L.; Hernandez, G.; Sandor, M.; Fabry, Z. Immune responses in stroke: How the immune system contributes to damage and healing after stroke and how this knowledge could be translated to better cures? Immunology 2018, 154, 363-376. [CrossRef] [PubMed]

91. Hu, X.; Li, P.; Guo, Y.; Wang, H.; Leak, R.K.; Chen, S.; Gao, Y.; Chen, J. Microglia/macrophage polarization dynamics reveal novel mechanism of injury expansion after focal cerebral ischemia. Stroke 2012, 43, 3063-3070. [CrossRef]

92. Patel, A.R.; Ritzel, R.; McCullough, L.D.; Liu, F. Microglia and ischemic stroke: A double-edged sword. Int. J. Physiol. Pathophysiol. Pharm. 2013, 5, 73-90.

93. Garcia-Bonilla, L.; Racchumi, G.; Murphy, M.; Anrather, J.; Iadecola, C. Endothelial CD36 Contributes to Postischemic Brain Injury by Promoting Neutrophil Activation via CSF3. J. Neurosci. 2015, 35, 14783-14793. [CrossRef] [PubMed]

94. Zhao, X.; Wang, H.; Sun, G.; Zhang, J.; Edwards, N.J.; Aronowski, J. Neuronal Interleukin-4 as a Modulator of Microglial Pathways and Ischemic Brain Damage. J. Neurosci. 2015, 35, 11281-11291. [CrossRef] [PubMed]

95. Szalay, G.; Martinecz, B.; Lénárt, N.; Környei, Z.; Orsolits, B.; Judák, L.; Császár, E.; Fekete, R.; West, B.L.; Katona, G.; et al. Microglia protect against brain injury and their selective elimination dysregulates neuronal network activity after stroke. Nat. Commun. 2016, 7, 11499. [CrossRef]

96. Jin, W.-N.; Shi, S.X.-Y.; Li, Z.; Li, M.; Wood, K.; Gonzales, R.J.; Liu, Q. Depletion of microglia exacerbates postischemic inflammation and brain injury. J. Cereb. Blood Flow Metab. 2017, 37, 2224-2236. [CrossRef]

97. Hawkins, K.E.; DeMars, K.M.; Alexander, J.C.; de Leon, L.G.; Pacheco, S.C.; Graves, C.; Yang, C.; McCrea, A.O.; Frankowski, J.C.; Garrett, T.J.; et al. Targeting resolution of neuroinflammation after ischemic stroke with a lipoxin A4 analog: Protective mechanisms and long-term effects on neurological recovery. Brain Behav. 2017, 7, e00688. [CrossRef]

98. Hu, X.; Leak, R.K.; Shi, Y.; Suenaga, J.; Gao, Y.; Zheng, P.; Chen, J. Microglial and macrophage polarization-new prospects for brain repair. Nat. Rev. Neurol. 2015, 11, 56-64. [CrossRef]

99. Clarke, D.T.W.; McMillan, N.A.J. Gene delivery: Cell-specific therapy on target. Nat. Nanotechnol. 2014, 9, 568-569. [CrossRef] [PubMed]

100. Milone, M.C.; O’Doherty, U. Clinical use of lentiviral vectors. Leukemia 2018, 32, 1529-1541. [CrossRef] [PubMed]

101. Anrather, J.; Iadecola, C. Inflammation and Stroke: An Overview. Neurotherapeutics 2016, 13, 661-670. [CrossRef] [PubMed]

102. Xiong, X.-Y.; Liu, L.; Yang, Q.-W. Functions and mechanisms of microglia/macrophages in neuroinflammation and neurogenesis after stroke. Prog. Neurobiol. 2016, 142, 23-44. [CrossRef] [PubMed] 
103. Hoek, R.M.; Ruuls, S.R.; Murphy, C.A.; Wright, G.J.; Goddard, R.; Zurawski, S.M.; Blom, B.; Homola, M.E.; Streit, W.J.; Brown, M.H.; et al. Down-regulation of the macrophage lineage through interaction with OX2 (CD200). Science 2000, 290, 1768-1771. [CrossRef]

104. Ahn, K.-C.; MacKenzie, E.M.; Learman, C.R.; Hall, T.C.; Weaver, C.L.; Dunbar, G.L.; Song, M.-S. Inhibition of p53 attenuates ischemic stress-induced activation of astrocytes. Neuroreport 2015, 26, 862-869. [CrossRef]

105. Choudhury, G.R.; Ryou, M.-G.; Poteet, E.; Wen, Y.; He, R.; Sun, F.; Yuan, F.; Jin, K.; Yang, S.-H. Involvement of p38 MAPK in reactive astrogliosis induced by ischemic stroke. Brain Res. 2014, 1551, 45-58. [CrossRef]

106. Rodriguez-Grande, B.; Swana, M.; Nguyen, L.; Englezou, P.; Maysami, S.; Allan, S.M.; Rothwell, N.J.; Garlanda, C.; Denes, A.; Pinteaux, E. The acute-phase protein PTX3 is an essential mediator of glial scar formation and resolution of brain edema after ischemic injury. J. Cereb. Blood Flow Metab. 2014, 34, 480-488. [CrossRef]

107. Xu, L.; Emery, J.F.; Ouyang, Y.-B.; Voloboueva, L.A.; Giffard, R.G. Astrocyte targeted overexpression of Hsp72 or SOD2 reduces neuronal vulnerability to forebrain ischemia. Glia 2010, 58, 1042-1049. [CrossRef]

108. Miao, Y.; Qiu, Y.; Lin, Y.; Miao, Z.; Zhang, J.; Lu, X. Protection by pyruvate against glutamate neurotoxicity is mediated by astrocytes through a glutathione-dependent mechanism. Mol. Biol. Rep. 2011, 38, 3235-3242. [CrossRef]

109. Ouyang, Y.-B.; Xu, L.; Yue, S.; Giffard, R. Neuroprotection by astrocytes in brain ischemia: Importance of microRNAs. Neurosci. Lett. 2013, 565. [CrossRef] [PubMed]

110. Shichita, T.; Sugiyama, Y.; Ooboshi, H.; Sugimori, H.; Nakagawa, R.; Takada, I.; Iwaki, T.; Okada, Y.; Iida, M.; Cua, D.J.; et al. Pivotal role of cerebral interleukin-17-producing gammadeltaT cells in the delayed phase of ischemic brain injury. Nat. Med. 2009, 15, 946-950. [CrossRef]

111. Gelderblom, M.; Weymar, A.; Bernreuther, C.; Velden, J.; Arunachalam, P.; Steinbach, K.; Orthey, E.; Arumugam, T.V.; Leypoldt, F.; Simova, O.; et al. Neutralization of the IL-17 axis diminishes neutrophil invasion and protects from ischemic stroke. Blood 2012, 120, 3793-3802. [CrossRef] [PubMed]

112. Liesz, A.; Zhou, W.; Mracskó, É.; Karcher, S.; Bauer, H.; Schwarting, S.; Sun, L.; Bruder, D.; Stegemann, S.; Cerwenka, A.; et al. Inhibition of lymphocyte trafficking shields the brain against deleterious neuroinflammation after stroke. Brain 2011, 134, 704-720. [CrossRef] [PubMed]

113. Sakaguchi, S.; Miyara, M.; Costantino, C.M.; Hafler, D.A. FOXP3+ regulatory T cells in the human immune system. Nat. Rev. Immunol. 2010, 10, 490-500. [CrossRef] [PubMed]

114. Liesz, A.; Suri-Payer, E.; Veltkamp, C.; Doerr, H.; Sommer, C.; Rivest, S.; Giese, T.; Veltkamp, R. Regulatory T cells are key cerebroprotective immunomodulators in acute experimental stroke. Nat. Med. 2009, 15, 192-199. [CrossRef]

115. Liesz, A.; Zhou, W.; Na, S.-Y.; Hämmerling, G.J.; Garbi, N.; Karcher, S.; Mracsko, E.; Backs, J.; Rivest, S.; Veltkamp, R. Boosting regulatory T cells limits neuroinflammation in permanent cortical stroke. J. Neurosci. 2013, 33, 17350-17362. [CrossRef]

116. Ito, M.; Komai, K.; Mise-Omata, S.; Iizuka-Koga, M.; Noguchi, Y.; Kondo, T.; Sakai, R.; Matsuo, K.; Nakayama, T.; Yoshie, O.; et al. Brain regulatory T cells suppress astrogliosis and potentiate neurological recovery. Nature 2019, 565, 246-250. [CrossRef]

117. Tuttolomondo, A.; Pecoraro, R.; Casuccio, A.; Di Raimondo, D.; Buttà, C.; Clemente, G.; Della Corte, V.; Guggino, G.; Arnao, V.; Maida, C.; et al. Peripheral Frequency of CD4+ CD28- Cells in Acute Ischemic Stroke. Medicine 2015, 94, e813. [CrossRef]

118. Nakajima, T.; Goek, O.; Zhang, X.; Kopecky, S.L.; Frye, R.L.; Goronzy, J.J.; Weyand, C.M. De novo expression of killer immunoglobulin-like receptors and signaling proteins regulates the cytotoxic function of CD4 T cells in acute coronary syndromes. Circ. Res. 2003, 93, 106-113. [CrossRef]

119. Tuttolomondo, A.; Di Raimondo, D.; Pecoraro, R.; Casuccio, A.; Di Bona, D.; Aiello, A.; Accardi, G.; Arnao, V.; Clemente, G.; Corte, V.D.; et al. HLA and killer cell immunoglobulin-like receptor (KIRs) genotyping in patients with acute ischemic stroke. J. Neuroinflamm. 2019, 16, 88. [CrossRef] [PubMed]

120. Yilmaz, G.; Arumugam, T.V.; Stokes, K.Y.; Granger, D.N. Role of T lymphocytes and interferon-gamma in ischemic stroke. Circulation 2006, 113, 2105-2112. [CrossRef] [PubMed]

121. Gurses, K.M.; Yalcin, M.U.; Kocyigit, D.; Canpinar, H.; Evranos, B.; Yorgun, H.; Sahiner, M.L.; Kaya, E.B.; Ozer, N.; Tokgozoglu, L.; et al. Effects of persistent atrial fibrillation on serum galectin-3 levels. Am. J. Cardiol. 2015, 115, 647-651. [CrossRef] 
122. Li, M.; Yang, G.; Xie, B.; Babu, K.; Huang, C. Changes in matrix metalloproteinase-9 levels during progression of atrial fibrillation. J. Int. Med. Res. 2014, 42, 224-230. [CrossRef]

123. Jensen, L.T. The aminoterminal propeptide of type III procollagen. Studies on physiology and pathophysiology. Dan. Med. Bull. 1997, 44, 70-78.

124. Naya, T.; Yukiiri, K.; Hosomi, N.; Takahashi, T.; Ohkita, H.; Mukai, M.; Koziol, J.A.; Kohno, M. Brain natriuretic peptide as a surrogate marker for cardioembolic stroke with paroxysmal atrial fibrillation. Cereb. Dis. 2008, 26, 434-440. [CrossRef]

125. Rodriguez-Yañez, M.; Arias-Rivas, S.; Santamaría, M.; Sobrino, T.; Castillo, J. High pro-BNP levels predict the occurrence of atrial fibrillation after cryptogenic stroke. Neurology 2013, 81. [CrossRef]

126. Tuttolomondo, A.; Di Raimondo, D.; Pecoraro, R.; Arnao, V.; Pinto, A.; Licata, G. Inflammation in ischemic stroke subtypes. Curr. Pharm. Des. 2012, 18, 4289-4310. [CrossRef]

127. Gökhan, S.; Ozhasenekler, A.; Mansur Durgun, H.; Akil, E.; Ustündag, M.; Orak, M. Neutrophil lymphocyte ratios in stroke subtypes and transient ischemic attack. Eur. Rev. Med. Pharm. Sci. 2013, 17, 653-657.

128. Zhao, L.; Dai, Q.; Chen, X.; Li, S.; Shi, R.; Yu, S.; Yang, F.; Xiong, Y.; Zhang, R. Neutrophil-to-Lymphocyte Ratio Predicts Length of Stay and Acute Hospital Cost in Patients with Acute Ischemic Stroke. J. Stroke Cereb. Dis. 2016, 25, 739-744. [CrossRef]

129. Nakase, T.; Yamazaki, T.; Ogura, N.; Suzuki, A.; Nagata, K. The impact of inflammation on the pathogenesis and prognosis of ischemic stroke. J. Neurol. Sci. 2008, 271, 104-109. [CrossRef] [PubMed]

130. Licata, G.; Tuttolomondo, A.; Di Raimondo, D.; Corrao, S.; Di Sciacca, R.; Pinto, A. Immuno-inflammatory activation in acute cardio-embolic strokes in comparison with other subtypes of ischaemic stroke. Thromb. Haemost. 2009, 101, 929-937. [PubMed]

131. Tuttolomondo, A.; Di Sciacca, R.; Di Raimondo, D.; Serio, A.; D’Aguanno, G.; La Placa, S.; Pecoraro, R.; Arnao, V.; Marino, L.; Monaco, S.; et al. Plasma levels of inflammatory and thrombotic/fibrinolytic markers in acute ischemic strokes: Relationship with TOAST subtype, outcome and infarct site. J. Neuroimmunol. 2009, 215, 84-89. [CrossRef]

132. Obermeier, B.; Daneman, R.; Ransohoff, R.M. Development, maintenance and disruption of the blood-brain barrier. Nat. Med. 2013, 19, 1584-1596. [CrossRef]

133. Rosenberg, G.A.; Yang, Y. Vasogenic edema due to tight junction disruption by matrix metalloproteinases in cerebral ischemia. Neurosurg. Focus 2007, 22, E4. [CrossRef]

134. Sumi, N.; Nishioku, T.; Takata, F.; Matsumoto, J.; Watanabe, T.; Shuto, H.; Yamauchi, A.; Dohgu, S.; Kataoka, Y. Lipopolysaccharide-activated microglia induce dysfunction of the blood-brain barrier in rat microvascular endothelial cells co-cultured with microglia. Cell Mol. Neurobiol. 2010, 30, 247-253. [CrossRef]

135. da Fonseca, A.C.C.; Matias, D.; Garcia, C.; Amaral, R.; Geraldo, L.H.; Freitas, C.; Lima, F.R.S. The impact of microglial activation on blood-brain barrier in brain diseases. Front. Cell Neurosci. 2014, 8, 362. [CrossRef]

136. Liu, J.; Jin, X.; Liu, K.J.; Liu, W. Matrix metalloproteinase-2-mediated occludin degradation and caveolin-1-mediated claudin-5 redistribution contribute to blood-brain barrier damage in early ischemic stroke stage. J. Neurosci 2012, 32, 3044-3057. [CrossRef]

137. Asahi, M.; Asahi, K.; Jung, J.C.; del Zoppo, G.J.; Fini, M.E.; Lo, E.H. Role for matrix metalloproteinase 9 after focal cerebral ischemia: Effects of gene knockout and enzyme inhibition with BB-94. J. Cereb. Blood Flow Metab. 2000, 20, 1681-1689. [CrossRef]

138. Rom, S.; Dykstra, H.; Zuluaga-Ramirez, V.; Reichenbach, N.L.; Persidsky, Y. miR-98 and let-7g* protect the blood-brain barrier under neuroinflammatory conditions. J. Cereb. Blood Flow Metab. 2015, 35, 1957-1965. [CrossRef]

139. Beurel, E. Regulation by glycogen synthase kinase- 3 of inflammation and T cells in CNS diseases. Front. Mol. Neurosci. 2011, 4, 18. [CrossRef]

140. Ramirez, S.H.; Fan, S.; Zhang, M.; Papugani, A.; Reichenbach, N.; Dykstra, H.; Mercer, A.J.; Tuma, R.F.; Persidsky, Y. Inhibition of glycogen synthase kinase 3beta (GSK3beta) decreases inflammatory responses in brain endothelial cells. Am. J. Pathol. 2010, 176, 881-892. [CrossRef]

141. Ramirez, S.H.; Fan, S.; Dykstra, H.; Rom, S.; Mercer, A.; Reichenbach, N.L.; Gofman, L.; Persidsky, Y. Inhibition of glycogen synthase kinase $3 \beta$ promotes tight junction stability in brain endothelial cells by half-life extension of occludin and claudin-5. PLoS ONE 2013, 8, e55972. [CrossRef] [PubMed] 
142. Neuwelt, E.; Abbott, N.J.; Abrey, L.; Banks, W.A.; Blakley, B.; Davis, T.; Engelhardt, B.; Grammas, P.; Nedergaard, M.; Nutt, J.; et al. Strategies to advance translational research into brain barriers. Lancet Neurol. 2008, 7, 84-96. [CrossRef]

143. Schober, A.; Zernecke, A. Chemokines in vascular remodeling. Thromb. Haemost. 2007, 97, 730-737. [PubMed]

144. Stamatovic, S.M.; Shakui, P.; Keep, R.F.; Moore, B.B.; Kunkel, S.L.; Van Rooijen, N.; Andjelkovic, A.V. Monocyte chemoattractant protein-1 regulation of blood-brain barrier permeability. J. Cereb. Blood Flow Metab. 2005, 25, 593-606. [CrossRef] [PubMed]

145. Fan, J.; Xu, W.; Nan, S.; Chang, M.; Zhang, Y. MicroRNA-384-5p Promotes Endothelial Progenitor Cell Proliferation and Angiogenesis in Cerebral Ischemic Stroke through the Delta-Likeligand 4-Mediated Notch Signaling Pathway. Cereb. Dis. 2020, 49, 39-54. [CrossRef] [PubMed]

146. $\mathrm{Xu}, \mathrm{A}$; Vanhoutte, P.M. Adiponectin and adipocyte fatty acid binding protein in the pathogenesis of cardiovascular disease. Am. J. Physiol. Heart Circ. Physiol. 2012, 302, H1231-H1240. [CrossRef] [PubMed]

147. Furuhashi, M.; Hotamisligil, G.S. Fatty acid-binding proteins: Role in metabolic diseases and potential as drug targets. Nat. Rev. Drug Discov. 2008, 7, 489-503. [CrossRef]

148. Xu, H.; Hertzel, A.V.; Steen, K.A.; Bernlohr, D.A. Loss of Fatty Acid Binding Protein 4/aP2 Reduces Macrophage Inflammation Through Activation of SIRT3. Mol. Endocrinol. 2016, 30, 325-334. [CrossRef]

149. Goldstein, L.B.; Adams, R.; Alberts, M.J.; Appel, L.J.; Brass, L.M.; Bushnell, C.D.; Culebras, A.; Degraba, T.J.; Gorelick, P.B.; Guyton, J.R.; et al. Primary prevention of ischemic stroke: A guideline from the American Heart Association/American Stroke Association Stroke Council: Cosponsored by the Atherosclerotic Peripheral Vascular Disease Interdisciplinary Working Group; Cardiovascular Nursing Council; Clinical Cardiology Council; Nutrition, Physical Activity, and Metabolism Council; and the Quality of Care and Outcomes Research Interdisciplinary Working Group: The American Academy of Neurology affirms the value of this guideline. Stroke 2006, 37, 1583-1633. [CrossRef] [PubMed]

150. Huang, X.-L. Association of Serum Levels of Adipocyte Fatty Acid-Binding Protein and High-Sensitivity C Reactive Protein with Severity of Acute Ischemic Stroke. Cell Biochem. Biophys. 2015, 72, 359-361. [CrossRef] [PubMed]

151. Liao, B.; Geng, L.; Zhang, F.; Shu, L.; Wei, L.; Yeung, P.K.K.; Lam, K.S.L.; Chung, S.K.; Chang, J.; Vanhoutte, P.M.; et al. Adipocyte fatty acid-binding protein exacerbates cerebral ischaemia injury by disrupting the blood-brain barrier. Eur. Heart J. 2020, 41, 3169-3180. [CrossRef] [PubMed]

152. Qin, B.; Yang, H.; Xiao, B. Role of microRNAs in endothelial inflammation and senescence. Mol. Biol. Rep. 2012, 39, 4509-4518. [CrossRef]

153. Long, G.; Wang, F.; Li, H.; Yin, Z.; Sandip, C.; Lou, Y.; Wang, Y.; Chen, C.; Wang, D.W. Circulating miR-30a, miR-126 and let-7b as biomarker for ischemic stroke in humans. BMC Neurol 2013, 13, 178. [CrossRef] [PubMed]

154. Leung, L.Y.; Chan, C.P.Y.; Leung, Y.K.; Jiang, H.L.; Abrigo, J.M.; Wang, D.F.; Chung, J.S.H.; Rainer, T.H.; Graham, C.A. Comparison of miR-124-3p and miR-16 for early diagnosis of hemorrhagic and ischemic stroke. Clin. Chim. Acta 2014, 433, 139-144. [CrossRef]

155. Xue, Y.; Wei, Z.; Ding, H.; Wang, Q.; Zhou, Z.; Zheng, S.; Zhang, Y.; Hou, D.; Liu, Y.; Zen, K.; et al. MicroRNA-19b/221/222 induces endothelial cell dysfunction via suppression of PGC-1 $\alpha$ in the progression of atherosclerosis. Atherosclerosis 2015, 241, 671-681. [CrossRef]

156. Hu, S.-L.; Cui, G.-L.; Huang, J.; Jiang, J.-G.; Wang, D.-W. An APOC3 3'UTR variant associated with plasma triglycerides levels and coronary heart disease by creating a functional miR-4271 binding site. Sci. Rep. 2016, 6, 32700. [CrossRef]

157. Wang, Y.; Zhuolin, M.; Kan, P.; Zhang, B. The Diagnostic Value of Serum miRNA-221-3p, miRNA-382-5p, and miRNA-4271 in Ischemic Stroke. J. Stroke Cerebrovasc. Dis. 2017, 26. [CrossRef]

158. Bao, Y.; Lin, C.; Ren, J.; Liu, J. MicroRNA-384-5p regulates ischemia-induced cardioprotection by targeting phosphatidylinositol-4,5-bisphosphate 3-kinase, catalytic subunit delta (PI3K p1108). Apoptosis 2013, 18, 260-270. [CrossRef]

159. Wang, B.; Zhong, Y.; Huang, D.; Li, J. Macrophage autophagy regulated by miR-384-5p-mediated control of Beclin-1 plays a role in the development of atherosclerosis. Am. J. Transl. Res. 2016, 8, 606-614.

160. Ogata, K.; Sumida, K.; Miyata, K.; Kushida, M.; Kuwamura, M.; Yamate, J. Circulating miR-9* and miR-384-5p as potential indicators for trimethyltin-induced neurotoxicity. Toxicol. Pathol. 2015, 43, 198-208. [CrossRef] 
161. Fasanaro, P.; Greco, S.; Ivan, M.; Capogrossi, M.C.; Martelli, F. microRNA: Emerging therapeutic targets in acute ischemic diseases. Pharm. Ther. 2010, 125, 92-104. [CrossRef] [PubMed]

162. Shi, F.; Dong, Z.; Li, H.; Liu, X.; Liu, H.; Dong, R. MicroRNA-137 protects neurons against ischemia/reperfusion injury through regulation of the Notch signaling pathway. Exp. Cell Res. 2017, 352, 1-8. [CrossRef] [PubMed]

163. Benedito, R.; Roca, C.; Sörensen, I.; Adams, S.; Gossler, A.; Fruttiger, M.; Adams, R.H. The notch ligands Dll4 and Jagged1 have opposing effects on angiogenesis. Cell 2009, 137, 1124-1135. [CrossRef]

164. Diez, H.; Fischer, A.; Winkler, A.; Hu, C.-J.; Hatzopoulos, A.K.; Breier, G.; Gessler, M. Hypoxia-mediated activation of Dll4-Notch-Hey2 signaling in endothelial progenitor cells and adoption of arterial cell fate. Exp. Cell Res. 2007, 313, 1-9. [CrossRef] [PubMed]

165. Sharghi-Namini, S.; Tan, E.; Ong, L.-L.S.; Ge, R.; Asada, H.H. Dll4-containing exosomes induce capillary sprout retraction in a 3D microenvironment. Sci. Rep. 2014, 4, 4031. [CrossRef]

166. Peng, Z.; Li, J.; Li, Y.; Yang, X.; Feng, S.; Han, S.; Li, J. Downregulation of miR-181b in mouse brain following ischemic stroke induces neuroprotection against ischemic injury through targeting heat shock protein A5 and ubiquitin carboxyl-terminal hydrolase isozyme L1. J. Neurosci. Res. 2013, 91, 1349-1362. [CrossRef]

Publisher's Note: MDPI stays neutral with regard to jurisdictional claims in published maps and institutional affiliations.

(C) 2020 by the authors. Licensee MDPI, Basel, Switzerland. This article is an open access article distributed under the terms and conditions of the Creative Commons Attribution (CC BY) license (http://creativecommons.org/licenses/by/4.0/). 